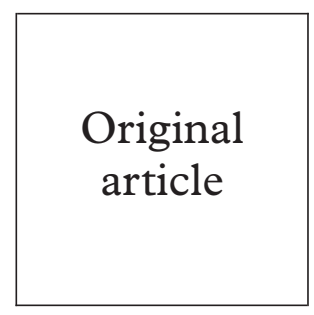

Original article

HIV and STD

Division, PHLS

Communicable

Disease Surveillance

Centre (CDSC),

61 Colindale Avenue,

London NW9 5EQ

G Hughes

M Catchpole

M Goldman

D Forsyth-Benson

$M$ Bond

A Myers

PHLS Statistics Unit, 61 Colindale Avenue, London NW9 5EQ

$\mathrm{N}$ Andrews

Correspondence to:

Dr G Hughes

Accepted for publication 22 September 1999

\title{
Investigation of the increased incidence of gonorrhoea diagnosed in genitourinary medicine clinics in England, 1994-6
}

Gwenda Hughes, Nick Andrews, Mike Catchpole, Matthew Goldman, Dorothy Forsyth-Benson, Marion Bond, Amanda Myers

Objectives: To determine important risk factors associated with cases of gonorrhoea in England, and whether any particular risk groups were associated with the substantial rise in numbers of cases seen between 1994 and 1996.

Design: Two retrospective cross sectional surveys.

Setting: 70 randomly selected genitourinary medicine (GUM) clinics in England.

Subjects: $10 \%$ of all gonorrhoea patients attending GUM clinics in England in 1994 (847 patients) and 1996 (1146 patients).

Main outcome measures: For risk factors in 1996 (study 1), unadjusted rates per 100000 population aged 14-70 and relative rates (RR) with 95\% confidence intervals (CIs). For the change in risk factors between 1994 and 1996 (study 2), adjusted odds ratios (ORs) with 95\% CIs, derived from logistic regression analyses of data on patients in 1996, with patients in 1994 as the comparison group.

Results: The incidence of gonorrhoea in 1996 was higher in homosexual males (812 per 100 000; $R R=30.2, \mathrm{CI}=25.2$ to 36.0) compared with heterosexual males (27 per 100 000); in black Caribbeans (467 per 100 000; 21.4, 17.9 to 25.5) and black Africans (235 per 100 000; $10.8,7.5$ to 15.5 ) compared with white people (22 per 100 000); and in previous GUM clinic attenders (433 per $100000 ; 37.93,35.46$ to 40.56) compared with those who had not attended previously (11 per 100 000). However, most patients were either white or heterosexual. Heterosexual patients in 1996 were significantly more likely to have reduced sensitivity to penicillin $(2.55,1.20$ to 5.41$)$ than those in 1994 . Male homo/bisexual patients in 1996 were significantly more likely to be from the north west $(3.77,1.45$ to 9.80$)$ and to have either reduced sensitivity $(2.63,1.03$ to 6.73$)$ or complete resistance $(1.98,1.03$ to 3.78$)$ to penicillin, compared with those in 1994.

Conclusions: Homo/bisexual men and the black Caribbean population in England experience a disproportionate burden of gonococcal infections, however, the bulk of diagnoses are in white heterosexuals. No single risk group was associated with the rise in numbers of cases between 1994 and 1996. Resistance to penicillin is widespread and has increased in homo/bisexual men, and it is possible that a rise in treatment failures has, to some extent, enhanced transmission of gonorrhoea and contributed to the rise in numbers of diagnoses in this group.

(Sex Transm Inf 2000;76:18-24)

Keywords: gonorrhoea; genitourinary medicine clinics; England

\section{Introduction}

Between 1995 and 1996, there was a $20 \%$ rise in the number of cases of gonorrhoea seen in genitourinary medicine (GUM) clinics in England. ${ }^{1}$ This followed a smaller increase between 1994 and $1995^{1}$ and the trend has continued into $1997 .{ }^{2}$ The rise between 1995 and 1996 was the largest proportional annual increase in diagnoses since 1945 (Communicable Disease Surveillance Centre (CDSC), unpublished data). It took place in almost every health region, occurred in heterosexuals as well as in homo/bisexual men, and was greatest in men and women aged $16-19$ years. ${ }^{1}$

Gonorrhoea rates are thought to be a reasonable indicator of changes in sexual behaviour. $^{3}$ The dramatic and substantial decline in numbers of people attending medicine GUM with gonorrhoea during the $1980 \mathrm{~s}^{4}$ may have resulted from changes in sexual behaviour in homosexual $\operatorname{men}^{356}$ as well as heterosexuals ${ }^{5}$ associated with the increased media coverage of AIDS. Gonorrhoea is the only sexually transmitted infection for which a target was set in the Health of the Nation ${ }^{7}$ as it was thought to be a convenient marker of behaviour likely to influence HIV transmission. ${ }^{7}$ Consequently, the resurgence of gonorrhoea diagnoses during the 1990 s is of considerable public health concern.

In looking for possible factors behind the recent rise it is noteworthy that higher rates of gonorrhoea among black groups than among the general white population have recently been highlighted in two urban areas. ${ }^{8}{ }^{9}$ However, as routine statistics from GUM clinics give limited risk factor information, ${ }^{10}$ it was not possible to determine whether black groups are at higher risk throughout England or if they contributed disproportionately to the latest increase.

This investigation had two aims. Firstly, we wished to determine important risk factors for 
gonorrhoea at the national level. Secondly, we examined whether the recent rise in numbers of gonorrhoea diagnoses was associated with changes in risk behaviours or with any particular risk group.

\section{Subjects and methods}

STUDY DESIGN AND SAMPLE SIZE

The investigation was in two parts: (1) an analysis of risk factors for gonorrhoea patients in 1996 (study 1), and (2) a comparison of risk factors for gonorrhoea in 1996 with those in 1994 to determine whether there had been a significant change in risk factors between these years (study 2). Two cross sectional surveys of gonorrhoea patients attending GUM clinics in 1994 and 1996 were carried out. A total sample size of about 2000 - that is, approximately $10 \%$ of all patients with gonorrhoea seen in GUM clinics in England in 1994 and 1996, was required in order to detect an odds ratio (OR) of 1.5 or more when $10 \%$ or more of patients in 1994 belonged to a risk group (5\% significance, $80 \%$ power). A necessity to analyse by sexual orientation meant that detectable ORs were 2.4 or more for homo/bisexual men and 1.7 or more for heterosexuals.

\section{SAMPLING STRATEGY}

Clinics

Two thirds of genitourinary medicine (GUM) clinics in inner London and a third of GUM clinics in the rest of England were randomly selected from each of nine size categories, determined by the number of gonorrhoea cases they reported in $1996(0-5,6-10,11-20$, $21-30,31-50,51-100,101-200,201-520$, or 521-1000). Inner London clinics were deliberately oversampled so that there were sufficient numbers for subgroup analyses of homosexual men. Nine of the 75 selected clinics (12\%) were unable to participate and were each replaced with another from the same size class. Four clinics reported no gonorrhoea cases and one was subsequently unable to participate, leaving 70 participating clinics.

\section{Subjects}

Listings of all patients attending with uncomplicated gonorrhoea (KC60 code B1B2) at each selected clinic in 1994 and 1996 were generated. One of the first four patients was randomly selected and, thereafter, every fourth patient. Repeat attenders were included. The following information was obtained from the patients' notes and recorded on a standard proforma: Clinic, patient number, date of attendance, sex, date of birth, site of infection, drug sensitivity (only qualitative data on drug sensitivity were collected-that is, we did not collect information on laboratory methodology and minimum inhibitory concentrations), drug given for treatment of gonorrhoea, ethnic group, country of birth, sexual orientation, marital status, number of partners in the past 3 months, sex abroad in the past 3 months, concurrent diagnoses, and date and diagnosis of any previous attendance at a GUM clinic.
DATA ANALYSIS

Unless otherwise specified, the data and analyses presented here include adjustments for the oversampling of patients from inner London clinics. Data from inner London clinics were downweighted by $50 \%$. As there were no more than six repeat attenders included in the data set, both within and between the 2 years, it was not deemed necessary to account for duplicates in the analyses. To determine whether the study patients were representative of all cases of gonorrhoea seen in GUM clinics, study cases from 1996 were compared by sex, age group, sexual orientation, and regional distribution to all gonorrhoea cases seen in GUM clinics in England in 1996 (KC60 data) ${ }^{1}$ using $\chi^{2}$ tests.

Study 1: Risk factors for cases in 1996

Numbers of patients from inner London clinics were halved to account for oversampling. Incidence rates per 100000 population aged 14-70 and relative rates were calculated for selected patient characteristics in 1996 with denominators derived from 1996 mid-year population estimates $^{11}$ (region, sex, and age estimates), the 1991 census $^{12}$ adjusted for undercoverage by age, sex, and ethnic group ${ }^{13}$ (ethnic group and area of birth estimates) and the National Study of Sexual Attitudes and Lifestyles $^{14}$ (sexual orientation and previous GUM clinic attendance estimates). To estimate incidence rates, the number of patients in 1996 was first multiplied by 12 (as after the London clinics were downweighted by $50 \%$ one twelfth of patients had been sampled). Relative rates (RRs) in 1996 were calculated from [C(e)/ $\mathrm{C}(\mathrm{b})] /[\mathrm{P}(\mathrm{e}) / \mathrm{P}(\mathrm{b})]$ where $\mathrm{C}(\mathrm{e})$ denotes the proportion of patients exposed, $\mathrm{C}(\mathrm{b})$ the proportion of patients with the baseline characteristic, $\mathrm{P}(\mathrm{e})$ the proportion of the population exposed, and $\mathrm{P}(\mathrm{b})$ the proportion of the population with the baseline characteristic.

Confidence intervals were calculated as for relative risks (equivalent in this case). Cases for which ethnicity was not recorded were assumed to be white and those for which country of birth was not recorded were assumed to have been born in the United Kingdom.

Study 2: Change in risk factors between 1994 and 1996

The odds ratios among those with the disease were compared directly between 1994 and 1996 using logistic regression with being a case in 1996 (as opposed to 1994) as the outcome variable. If a factor is not associated with the outcome variable then the increase in cases observed between 1994 and 1996 is similar in the groups defined by the factor. It was not possible to calculate odds ratios for many sexual behaviour and clinical characteristics for 1994 and 1996 directly, as data on the frequency of these characteristics in the general population are not available. For this method it was assumed that the proportion of the population belonging to a given risk group changed little between 1994 and 1996.

Univariable and multivariable analyses were carried out using STATA software. ${ }^{15}$ Data for patients from inner London clinics were given 
a sampling weighting of 6 , and those from remaining clinics a weighting of 12 , since the probabilities of patients from these areas being included in the sample were $1 / 6$ and $1 / 12$, respectively (using the [pweight=] command in stata $^{15}$ ). All patient and infection characteristics collected on the proforma were compared between cases in 1994 and 1996 using univariable analyses. Only those factors which were significant at $\mathrm{p}<0.2$ in the univariable analyses (sex, sex abroad, previous GUM clinic attendance, concurrent acute sexually transmitted infection (STI), site, sensitivity to penicillin, treatment), and those which were of particular interest (region, age, ethnic group, number of partners, previous acute STI), were included as explanatory variables in the multivariable models. Separate models were run for heterosexuals and for homo/bisexual men because the distribution of many demographic and behavioural characteristics varied considerably between these groups. In the heterosexual model, interactions between sex and each of the explanatory variables were investigated. As

Table 1 Estimated incidence of gonorrhoea cases diagnosed in GUM clinics in 1996 by selected characteristics

\begin{tabular}{|c|c|c|c|c|}
\hline Factor & $\begin{array}{l}\text { Number of } \\
\text { cases }^{*}(\%)\end{array}$ & $\begin{array}{l}\text { Rate per } 100000 \\
\text { populationt }\end{array}$ & Relative & e rate $(95 \% C I)$ \\
\hline \multicolumn{5}{|l|}{ Region } \\
\hline North Thames & $211(25)$ & 56 & 1.00 & \\
\hline South Thames & $89(11)$ & 42 & 0.76 & $(0.63,0.93)$ \\
\hline North West & $148(17)$ & 38 & 0.68 & $(0.55,0.84)$ \\
\hline Northern and Yorkshire & $37(4)$ & 10 & 0.18 & $(0.12,0.25)$ \\
\hline Trent & $108(13)$ & 35 & 0.64 & $(0.51,0.80)$ \\
\hline Anglia and Oxford & $46(5)$ & 14 & 0.26 & $(0.19,0.35)$ \\
\hline South and West & $55(6)$ & 14 & 0.25 & $(0.19,0.34)$ \\
\hline West Midlands & $49(6)$ & 15 & 0.28 & $(0.21,0.38)$ \\
\hline \multicolumn{5}{|l|}{ Sex } \\
\hline Female & $268(32)$ & 18 & 1.00 & \\
\hline Male & $579(68)$ & 39 & 2.14 & $(1.90,2.40)$ \\
\hline \multicolumn{5}{|l|}{ Age group } \\
\hline $13-15$ & $11(1)$ & 12 & 0.13 & $(0.07,0.24)$ \\
\hline $16-19$ & $159(19)$ & 83 & 1.00 & \\
\hline $20-24$ & $224(27)$ & 85 & 1.02 & $(0.84,1.25)$ \\
\hline $25-29$ & $181(22)$ & 57 & 0.68 & $(0.55,0.83)$ \\
\hline $30-34$ & $124(15)$ & 36 & 0.44 & $(0.35,0.55)$ \\
\hline $35-44$ & $103(12)$ & 18 & 0.21 & $(0.17,0.27)$ \\
\hline $45-70$ & $23(3)$ & 2 & 0.03 & $(0.02,0.04)$ \\
\hline Not recorded & $24(3)$ & - & - & \\
\hline \multicolumn{5}{|l|}{ Male sexual orientation } \\
\hline Heterosexual & $385(66)$ & 27 & 1.00 & \\
\hline Homo/bisexual & $166(29)$ & 812 & 30.15 & $(25.22,36.04)$ \\
\hline Not known & $29(5)$ & - & - & \\
\hline \multicolumn{5}{|l|}{ Female sexual orientation } \\
\hline Heterosexual & $260(97)$ & 18 & 1.00 & \\
\hline Homo/bisexual & $2(1)$ & 23 & 1.28 & $(0.32,5.15)$ \\
\hline Not recorded & $7(2)$ & - & - & \\
\hline \multicolumn{5}{|l|}{ Ethnic group } \\
\hline White & $362(43)$ & $22 \ddagger$ & $1.00 \ddagger$ & \\
\hline Black Caribbean & $155(18)$ & 467 & 21.36 & $(17.91,25.47)$ \\
\hline Black African & $31(4)$ & 235 & 10.77 & $(7.51,15.45)$ \\
\hline Indian/Pakistani/Bangladeshi & $18(2)$ & 22 & 1.02 & $(0.64,1.63)$ \\
\hline Other/mixed & $32(4)$ & 72 & 3.29 & $(2.30,4.69)$ \\
\hline Not recorded & $251(30)$ & - & - & \\
\hline \multicolumn{5}{|l|}{ Area of birth } \\
\hline UK & $614(72)$ & $21 \S$ & $1.00 \$$ & \\
\hline Rest of Europe & $31(4)$ & 31 & 1.50 & $(1.05,2.16)$ \\
\hline Latin America and Caribbean & $28(3)$ & 112 & 5.43 & $(3.72,7.91)$ \\
\hline Africa & $17(2)$ & 64 & 3.08 & $(1.91,4.99)$ \\
\hline Other & $23(3)$ & 16 & 0.77 & $(0.51,1.17)$ \\
\hline Not recorded & $135(16)$ & - & - & \\
\hline \multicolumn{5}{|l|}{ Previous GUM attendance } \\
\hline No & $324(51)$ & 11 & 1.00 & \\
\hline Yes & $374(44)$ & 433 & 37.93 & $(35.46,40.56)$ \\
\hline Not recorded & $34(5)$ & & - & \\
\hline
\end{tabular}

*Adjusted for oversampling of inner London GUM clinics.

†Population sizes were estimated using data from mid-year population estimates for $1996^{11}$ (region, sex, and age estimates), the 1991 census $^{12}$ adjusted for undercoverage by age, sex, and ethnic group ${ }^{13}$ (ethnic group and area of birth estimates), and the National Study of Sexual Attitudes and Lifestyles ${ }^{14}$ (sexual orientation and previous GUM clinic attendance estimates).

$\ddagger$ Includes patients for whom ethnic group was not recorded.

fIncludes patients for whom country of birth was not recorded. there were strong regional differences in the recording of ethnic group in patients' case notes, interactions between region and the presence or absence of ethnic group data were investigated in both models.

\section{Results}

Data were collected on 847 patients in 1994 and 1146 patients in 1996, giving an unadjusted total of 1993 patients overall. Just over half of these patients were seen in inner London clinics.

The study patients in 1996 were not significantly different from all cases reported in the 1996 KC60 data set by sex $\left(\chi^{2}=1.2 ; \mathrm{df}=1 ; \mathrm{p}\right.$ $=0.27)$ or age $\left(\chi^{2}=4.1 ; \mathrm{df}=3 ; \mathrm{p}=0.25\right)$. However, $30 \%$ of males in the study in 1996 were homosexual or bisexual, significantly more than the $21 \%$ reported nationally $\left(\chi^{2}=24.4\right.$; df $=1 ; \mathrm{p}<0.001)$. The regional distribution also differed significantly between the two data sets $\left(\chi^{2}=91.9 ; \mathrm{df}=7 ; \mathrm{p}<0.001\right)$. Patients from the North West and West Midlands accounted for higher and lower proportions, respectively, of patients in the study than all cases.

\section{STUDY 1: RISK FACTORS FOR GONORRHOEA} PATIENTS IN 1996

The distributions of patients in 1996 (adjusted for London oversampling) are presented by region, sex, age group, sexual orientation, ethnic group, area of birth, and previous GUM clinic attendance in table 1.

White people were the largest ethnic group nationally and in all regions except South Thames. Northern and Yorkshire was the only region with no black Caribbean patients recorded and, in the remaining regions, the proportion of patients who were black Caribbean ranged from $4 \%$ in the North West to $62 \%$ in South Thames. Overall, ethnic group was not recorded for $30 \%$ of patients although this ranged from $6 \%$ in Trent to $67 \%$ in the North West. Ethnic group was not recorded for $10 \%$ of patients in South Thames, for 13\% in North Thames, and for $20 \%$ in the West Midlands. Seventy four per cent of white people and 96\% of black Caribbeans were heterosexual.

Twenty nine per cent of patients in 1996 had a concurrent acute sexually transmitted infections (STI) (see box) and $22 \%$ had previously had an acute STI. Eight per cent had a penicillin resistant gonococcal strain (that is, all penicillinase producing Neisseria gonorrhoeae (PPNG) and chromosomally mediated penicillin resistant $N$ gonorrhoeae (CMRNG)) whereas less than $1 \%$ were resistant to quinolones or to tetracycline. Penicillin resistance was more common in homo/bisexual men, with $18 \%$ of patients resistant, compared with women and heterosexual men, with $4 \%$ and $7 \%$ resistant, respectively.

Site of infection was recorded for $98 \%$ of patients in 1996. Ninety per cent of females, over $99 \%$ of heterosexual males, and $67 \%$ of homo/bisexual men had genital gonorrhoea. Rectal gonorrhoea was found in $24 \%$ of homo/ bisexual men and $10 \%$ of females, but not in heterosexual males. Throat infections were 


\begin{tabular}{|l|}
\hline Definition of an acute sexually \\
transmitted infection \\
Infectious syphilis \\
Uncomplicated gonorrhoea \\
Complicated gonorrhoea \\
Chancroid/lymphogranuloma venereum/ \\
donovanosis \\
Uncomplicated chlamydial infection \\
Complicated chlamydial infection \\
Uncomplicated non-gonococcal/non- \\
specific urethritis in males \\
Complicated non-gonococcal/non-specific \\
infection \\
Herpes simplex (first attack) \\
Wart virus infection (first attack) \\
Molluscum contagiosum \\
Trichomoniasis \\
Scabies/pediculosis
\end{tabular}

found in $9 \%$ of homo/bisexual men but in less than $1 \%$ of heterosexual men and women.

Number of partners in the past 3 months, and sex abroad in the past 3 months, was recorded for $98 \%$ and $92 \%$, respectively, of patients in 1996 . Twenty nine per cent of heterosexual females, $54 \%$ of heterosexual males, and $59 \%$ of homo/bisexual males reported two or more partners during this period. Five per cent of patients reported sex abroad.

Incidence and relative rates for selected characteristics of patients in 1996 are shown in table 1. Incidence was particularly high for homo/ bisexual males compared with heterosexual males, black Caribbean and black African cases relative to white cases, and for those who had previously attended a GUM clinic.

STUDY 2: CHANGE IN RISK FACTORS FOR GONORRHOEA BETWEEN 1994 AND 1996

Descriptive analyses

Between 1994 and 1996, diagnoses in females rose by $25 \%$ (215 to 268 ), in heterosexual males by $46 \%$ (263 to 385), and in homo/ bisexual males by $31 \%$ (126 to 166). In females, the largest increase was in 16-19 year olds and percentage increases diminished with age (fig 1A). In heterosexual males large rises occurred across most age groups (fig 1B) while in homo/bisexual males, the largest proportional increases were in the over 35s (fig 1C).

Multivariable analyses

Adjusted risk factors for being a gonorrhoea patient in 1996 compared to being a patient in 1994 are presented in table 2 .

For heterosexuals, patients in 1996 were significantly more likely to be males, to have had no or one sexual partners in the past 3 months compared with two, and to have reduced sensitivity to penicillin than cases in 1994. There were no interactions between sex and any of the explanatory variables in the model.

For homo/bisexual men, patients in 1996 were significantly more likely to be from the North West and to have either reduced sensitivity or complete resistance to penicillin than cases in 1994.
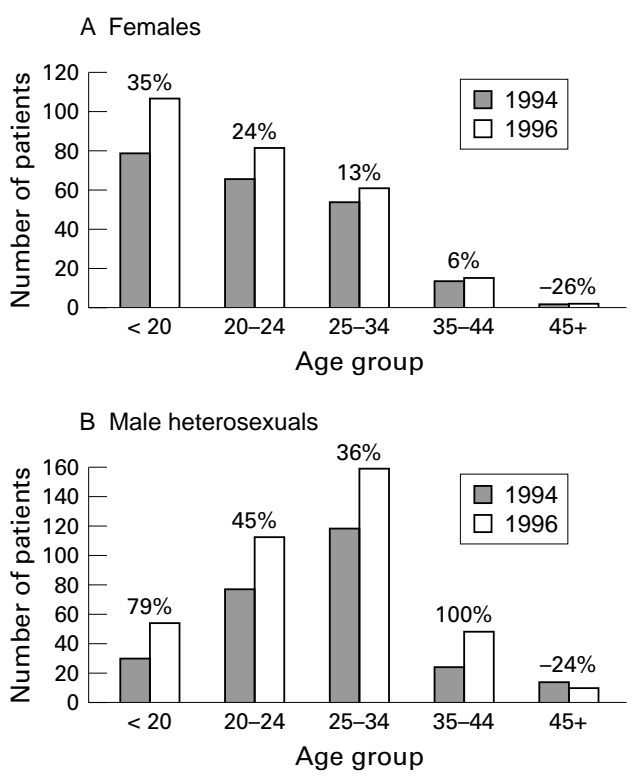

C Male homo/bisexuals

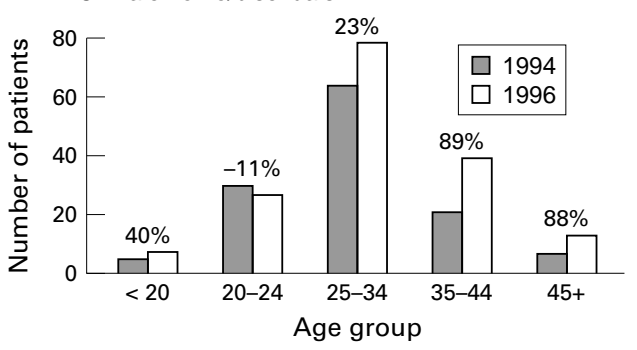

Figure 1 Gonorrhoea patients in 1994 and 1996 by age group: numbers of patients adjusted for oversampling in inner London clinics and percentage changes

There was evidence for an interaction between region and the presence or absence of ethnic data $\left(\chi^{2}=13.7, \mathrm{df}=7, \mathrm{p}=0.057\right.$ for the heterosexual model; $\chi^{2}=14.6, \mathrm{df}=3, \mathrm{p}=0.002$ for the male homo/bisexual model). Clinics in the Thames regions improved the recording of ethnic data between 1994 and 1996, whereas clinics in other regions did not.

\section{Discussion}

We report on the first national investigation of risk factors associated with cases of gonorrhoea, and of possible causes of the recent rise in numbers of diagnoses, in a study which sampled $10 \%$ of all gonorrhoea patients attending GUM clinics in England in 1994 and 1996. Overall, gonorrhoea patients selected for this study were found to be fairly representative of all gonorrhoea cases seen in GUM clinics in England. The oversampling of cases from the North West and of homo/bisexual men probably arose from the random sampling of particularly large clinics in the North West, and of clinics attended predominantly by homo/ bisexual men. Consequently, the incidence and relative rate of gonorrhoea in homo/bisexual men and in the North West region in 1996 are likely to be overestimated.

STUDY 1: RISK FACTORS FOR GONORRHOEA PATIENTS IN 1996

The high rates of gonorrhoea in homo/bisexual men are of continuing concern. This study 
Table 2 Adjusted risk factors for being a case of gonorrhoea in 1996 compared with being a case in 1994

\begin{tabular}{|c|c|c|c|c|c|c|}
\hline \multirow[b]{2}{*}{ Variable } & \multicolumn{3}{|c|}{ Heterosexual men and women $(n=1173)$} & \multicolumn{3}{|c|}{ Homo/bisexual men $(n=388)$} \\
\hline & $\begin{array}{l}\text { Odds ratio } \\
\text { (adjusted) }\end{array}$ & $95 \% C I$ & $p$ Value & $\begin{array}{l}\text { Odds ratio } \\
\text { (adjusted) }\end{array}$ & $95 \% C I$ & $p$ Value \\
\hline \multicolumn{7}{|l|}{ Sex } \\
\hline Male & 1.00 & & & \multicolumn{3}{|c|}{ Not applicable } \\
\hline Female & 0.72 & $0.53-0.97$ & 0.02 & & & \\
\hline \multicolumn{7}{|l|}{ Region } \\
\hline North Thames & 1.00 & & & 1.00 & & \\
\hline South Thames & 0.97 & $0.67-1.39$ & & 1.87 & $0.91-3.82$ & \\
\hline North West & 1.54 & $0.88-2.70$ & & 3.77 & $1.45-9.80$ & \\
\hline Northern and Yorkshire & 2.03 & $0.86-4.81$ & & 0.15 & $0.01-3.01$ & \\
\hline Trent & 0.82 & $0.51-1.31$ & & 1.13 & $0.32-4.04$ & \\
\hline Anglia and Oxford & 0.81 & $0.46-1.44$ & & 1.18 & $0.38-3.69$ & \\
\hline South and West & 0.80 & $0.44-1.47$ & & 1.17 & $0.32-4.30$ & 0.004 \\
\hline West Midlands & 1.21 & $0.65-2.27$ & 0.06 & 一未 $^{\star}$ & & \\
\hline Age & 0.99 & $0.98-1.02$ & 0.97 & 1.01 & $0.98-1.05$ & 0.40 \\
\hline \multicolumn{7}{|l|}{ Ethnic group } \\
\hline White & 1.00 & & & 1.00 & & \\
\hline Black Caribbean & 1.24 & $0.85-1.80$ & & $6.68+$ & $0.70-63.43$ & \\
\hline Black African & 0.63 & $0.35-1.13$ & & 1.78 & $0.41-7.71$ & \\
\hline Indian/Pakistani/Bangladeshi & 0.63 & $0.28-1.38$ & & $-\star$ & & \\
\hline Other/mixed & 0.72 & $0.39-1.33$ & 0.09 & 0.67 & $0.13-3.53$ & 0.04 \\
\hline \multicolumn{7}{|l|}{ Partners in last 3 months } \\
\hline $0-1$ & 1.00 & & & 1.00 & & \\
\hline 2 & 0.70 & $0.52-0.93$ & & 0.96 & $0.56-1.63$ & \\
\hline 3 or more & 1.07 & $0.64-1.79$ & 0.02 & 1.36 & $0.72-2.56$ & 0.69 \\
\hline Sex abroad in past 3 months & 0.71 & $0.39-1.28$ & 0.22 & —* & & \\
\hline Previous GUM clinic attendance & 0.75 & $0.52-1.08$ & 0.10 & 0.85 & $0.49-1.47$ & 0.53 \\
\hline Concurrent acute STI & 1.24 & $0.93-1.65$ & 0.13 & 0.99 & $0.48-2.04$ & 0.97 \\
\hline Previous acute STI & 1.19 & $0.79-1.80$ & 0.39 & 1.40 & $0.78-2.51$ & 0.26 \\
\hline \multicolumn{7}{|l|}{ Site of infection $\ddagger$} \\
\hline Genital & 1.00 & & & 1.00 & & \\
\hline Rectal & 1.74 & $0.81-3.73$ & & 0.92 & $0.54-1.57$ & \\
\hline Throat & 1.78 & $0.34-9.35$ & 0.26 & 0.78 & $0.36-1.69$ & 0.79 \\
\hline \multicolumn{7}{|l|}{ Sensitivity to penicillin } \\
\hline Sensitive & 1.00 & & & 1.00 & & \\
\hline Reduced sensitivity & 2.55 & $1.20-5.41$ & & 2.63 & $1.03-6.73$ & \\
\hline Resistant & 0.76 & $0.47-1.27$ & 0.01 & 1.98 & $1.03-3.78$ & 0.02 \\
\hline \multicolumn{7}{|l|}{ Treatment $\$$} \\
\hline Penicillin & 1.00 & & & 1.00 & & \\
\hline Quinolone & 0.92 & $0.66-1.30$ & & 1.12 & $0.66-1.90$ & \\
\hline Other drug type & 0.71 & $0.42-1.20$ & 0.36 & 0.33 & $0.09-1.20$ & 0.10 \\
\hline
\end{tabular}

^Not estimable owing to small numbers.

†Estimated from one patient in 1994 and six patients in 1996

$\ddagger$ Multiple site infections were categorised as follows: "rectal" includes concurrent genital, throat, and "other" infections, "genital” includes concurrent throat and "other" infections but not rectal infections, and "throat" includes infections of the throat only.

\Relates solely to drugs given to treat gonococcal infection. For multiple treatments "quinolone" includes penicillin treatment and "other drug type" includes penicillin and/or quinolone treatment.

indicated that about a quarter of infections in homo/bisexual men were rectal, whereas infections of the throat only, indicative of safer sexual behaviour in terms of HIV transmission, ${ }^{16}$ made up fewer than $10 \%$ of cases. Variations on policy on anatomical sites routinely screened for gonorrhoea may have led to an underestimate of the proportion of rectal and throat infections. Clearly, however, many homo/bisexual men attending GUM clinics with gonorrhoea have placed themselves at risk of HIV infection through unsafe sexual practice. In 1997, an estimated $9 \%$ of homo/ bisexual men attending GUM clinics in London, and $4 \%$ attending clinics elsewhere in England and Wales, were infected with HIV. ${ }^{17}$

At the national level, incidence of gonorrhoea was far higher for black Caribbeans, who constituted at least $18 \%$ of all patients, than for white people. This is in accordance with results from localised studies. ${ }^{89}$ None the less, the bulk of gonorrhoea patients were white heterosexuals.

Recording of ethnicity tended to be better in the Thames regions, which along with the West Midlands have much higher black ethnic minority populations. ${ }^{12}$ To prevent overestimation of relative rates for gonorrhoea in ethnic minorities, cases for which ethnicity and/or country of birth data were not recorded were assumed to be white and/or born in the United Kingdom. This was reasonable since areas with the most missing data have relatively small black ethnic minority populations. The likely effect of misclassification due to this assumption will have been to underestimate the size of relative rates associated with non-white ethnic groups. Variations in the methods of recording ethnicity (such as whether ethnicity is assigned by the patient or clinic reception staff) also place limitations on the robustness of ethnic groupings.

Despite these limitations, this study confirms that the black Caribbean population experiences a disproportionate burden of gonococcal infections. The reasons for the unequal distribution of gonorrhoea across ethnic groups are likely to be complex. Sexual behaviours and mixing patterns are determined by cultural background to a large extent ${ }^{18}$ resulting in variations in the transmission patterns of STIs by ethnic group. As people more often have sexual partners within their own ethnic group, ${ }^{19}$ existing high levels of infection are likely to be maintained. ${ }^{18}$ However, there are known racial inequalities in socioeconomic status and in the access to, and use of, healthcare services, ${ }^{18} 20$ with ethnic minorities being less likely to have access to good 
medical care. ${ }^{20}$ Such inequalities could facilitate infection transmission by limiting access to treatment and the effectiveness of partner notification. None the less, certain studies have suggested that disparities in gonorrhoea prevalence by ethnic group may exist even when controlling for socioeconomic status. ${ }^{89}$

The study suggests that almost one in five homo/bisexual men and about one in 16 heterosexuals presenting with gonorrhoea at GUM clinics in England in 1996 had a penicillin resistant strain. In homo/bisexual men, resistance of gonococcal strains to penicillin had also increased significantly since 1994. Unfortunately, in this study we did not collect information on type of resistance and minimum inhibitory concentration ranges. As there is likely to be considerable variability in the methodology used for measuring resistance, this somewhat limits the significance of this finding. None the less, samples submitted to the genitourinary infection reference laboratory in Bristol indicate that chromosomally mediated resistance to penicillin has been increasing since 1994, whereas penicillinase producing (plasmid) gonococcal strains have declined since $1989 .^{21}$ Penicillin is still the preferred treatment for gonorrhoea in many clinics in the United Kingdom $^{22}$ and the findings from this study warrant a review of recommended treatment of gonorrhoea at the local, if not the national, level, especially in homo/bisexual men.

Almost half the cases in 1996 had previous contact with GUM clinic services and had presumably received advice on safer sexual behaviour. It is also noteworthy that older homo/ bisexual men experienced a greater (though non-significant) rise than younger homo/ bisexual men, despite the fact that these men are most likely to have been exposed to the HIV safer sex campaigns in the 1980s. There appears to be scope for improvements in sexual health promotion in GUM clinics as a priority area for the control and prevention of gonorrhoea.

STUDY 2: CHANGE IN RISK FACTORS FOR

GONORRHOEA BETWEEN 1994 AND 1996

There is no evidence to suggest that the rise in cases of gonorrhoea seen at GUM clinics in England between 1994 and 1996 was driven by any single risk group. The rise was greatest in heterosexual men but there were also large rises in women and in homo/bisexual men. It is particularly important to recognise that although black Caribbeans are at higher risk than whites for the acquisition of gonorrhoea, the rate of increase of new cases in whites and black Caribbeans was similar. Recording of ethnicity improved in the Thames regions between 1994 and 1996, but not elsewhere, and this may explain the slightly higher (though nonsignificant) odds ratios associated with black Caribbeans compared with white people. Otherwise, the odds ratios calculated for study 2 are likely to be valid, as a major shift in the size of the various population subgroups between 1994 and 1996 is unlikely.

It is possible that the rise reflects an increase in incidence following sexual behaviour changes generally. A smaller increase in numbers of diagnoses among homosexual men in 1989 and 1990 was associated with changes in risk behaviour which resulted in increased HIV transmission in this group. ${ }^{23}$ Furthermore, the significant increases in penicillin resistant gonorrhoea observed in homo/bisexual men in this study may also have increased the likelihood of treatment failure in this group. If so, it is possible that this enhanced gonorrhoea transmission in homo/bisexual men to some extent and contributed to the rise in numbers of diagnoses.

It is also possible that the rise in numbers of diagnoses could be contributed to by changes in the use of genitourinary medicine services, such as changes in health seeking behaviour resulting from sexual health promotion initiatives, or increased referrals from other healthcare settings. A change in attendance resulting from successful health promotion initiatives is perhaps unlikely in this case. Heterosexual males were the largest group in this study, and they experienced the greatest rise. Almost all infections in heterosexual males were genital, and as genital infections in males are usually symptomatic, it is reasonable to conjecture that attendance at the GUM clinic in this group was stimulated by the presence of symptoms. Also, a study of 70000 attenders at 18 general practices in 1994 found very few were treated for gonorrhoea in this setting (unlike those who presented with genital herpes and warts, half of whom were treated in general practice without being referred to GUM clinics), such that a major shift from general practice to GUM clinics for the treatment of gonorrhoea seems implausible (CDSC, unpublished data).

In heterosexual patients, the rise among teenage females was not significantly greater than in older females but may represent a general sexual health problem in that group. ${ }^{24}$ The increased number of patients reporting only one sexual partner may be due to increased flow of infections from high risk core groups ${ }^{25}$ to non-core groups, resulting in a greater proportion of cases in 1996 reporting only one sexual partner. Caution with this interpretation is required, however, given the likelihood of variations in accuracy and recording of information on numbers of partners.

Homosexually acquired gonorrhoea increased particularly in the North West. Given the substantial caseload of HIV infections in the Manchester area ${ }^{17}$ this demonstrates the value of gonorrhoea surveillance data in indicating where there is a potential or real need for local public health action.

The study protocol was submitted to the Public Health Laboratory Service ethics committee who, after consultation with the chairman of the South Thames multicentre research ethics committee (MREC), felt that this study was essentially an outbreak investigation designed to inform immediate public health policy and, as such, did not require ethical approval.

The study would not have been possible without the commitment and hard work of medical, nursing, and administrative staff at all the participating GUM clinics. They are gratefully acknowledged. The authors also wish to thank Dr A Swan and Mrs P Rogers for Mrs P Rogers for additional statistical input, Mr A Brady, Dr K Fenton, Dr G Luzzi, Mr N Macdonald, Dr Macdonald-Burns, Dr A Nicoll, Mr I Simms, Dr M Tennant-Flowers, and Dr N Thin for helpful comments on an earlier draft of this paper, an Mrs P Deeks and Ms S Wellstead for administrative support.
Contributors: GH, NA, and MC designed the study; GH analysed the results with statistical guidance from NA; GH, MC, 
MG, MB, DF-B and AM were involved in interpretation of the results; $\mathrm{GH}$ and $\mathrm{MG}$ coordinated the study with the help of $\mathrm{MB}$, DF-B, and AM; GH undertook the main writing of the paper.

The following clinicians and clinics participated in the study.

Anglia and Oxford

Dr Shanmugaratnan, Bedford Hospital; Dr Fawcett, Peterborough Distriat Hospital (Fenland Wing); Dr Greenhouse, Ipswich Hospital; Dr Carne, Addenbrooke's Hospital, Cambridge; Dr Luzzi, Wycombe General Hospital; Dr Sherrard, Orchard Health Centre, Banbury.

North Thames

Dr Simmons, St Bartholomew's Hospital; Dr Forster, Roya London Hospital; Dr Macdonald-Burns, Royal Free Hospital; Dr Murphy, Central Middlesex Hospital (Patrick Clements Clinic); Dr Maiti, Hertford County Hospital; Dr Weir, Barnet General Hospital; Dr Jebakumar, Halstead Hospital; D Coehlo, St John's Hospital, Chelmford; Dr Daniel, West Middlesex University Hospital; Dr Kell, Whittington Hospital (Archway Sexual Health Clinic); Dr Mercey, Mortimer Market Centre; Dr Wisdom, Newham General Hospital; Dr John, Hemel Hempstead General Hospital; Dr McLean, Charing Cross Hospital (Chelsea and Westminster); Dr Lawrence, Westminister Hospital (Victoria Clinic); Dr Barton, St Stephens Centre (John Hunter Clinic).

North West

Dr Chatterjee and Dr Mandal, Manchester Royal Infirmary; Dr Lacey, Ballie Street Health Centre, Rochdale; Dr O'Mahony, Countess of Chester Hospital; Dr Forrer, Royal Albert Edward Infirmary, Wigan; Dr Woolley, Trafford General Hospital, Manchester; Dr Curless, Bolton General Hospital; Dr Higgins, Manchester; Dr Curless, Bolton General Hospital; Dr Higgins, Horth Mital; Dr Ahmed, Tameside General Hospital, Ashton under Lyne.

Northern and Yorkshire

Dr Bavidge, Harrogate District Hospital; Dr Rajah, North Tees General Hospital, Stockton on Tees; Dr Opaneye, Middlesborough General Hospital; Dr Stanley, Workington Infirmary; Dr Sarnara Dr Watson, Tynemouth Victoria Jubilee Infirmary, North Shields; Dr Al-Egaily, Princess Royal Community Health Centre, Huddersfield.

South and West

Dr Sulaiman, Cheltenham General Hospital (Benhall Clinic); Dr Wilcox, Torbay Hospital, Torquay; Dr George, North Devon District General Hospital, Barnstable; Dr Basu-Roy, Panel Suite, Royal Bournemouth Hospital; Dr Keane, Royal Cornwall Hospital, Truro; Dr Sulaiman, Gloucester Royal Hospital; D Baksi, St Mary's Hospital, Isle of Wight; Dr Tobin, St Mary's Hospital, Portsmouth; Dr Morrison, Freedom Fields Hospital Plymouth; Dr Woodcock, Royal Hampshire County Hospital; Dr Rabindran, Chippenham Community Hospital; Dr Kazi, Princess Margaret Hospital, Swindon; Dr Jackson, North Hampshire Hospital (Basingstoke District Hospital).

South Thames

Dr Sarkhel, Folkestone Health Centre; Dr Patel, Ore Clinic, Hastings; Dr Pritchard, St Peter's Hospital (Blancity Heriot Unit), Chertsey; Dr Nayagam, Claude Nicol Centre, Brighton; Dr Patel, Avenue House, Eastbourne; Dr Deheragoda, East Surrey Hospital, Redhill; Dr Rodgers and Dr Theodore, Mayday University Hospital, Thornton Heath; Dr Welch, Kayday University Hospital, Thornton Heath; Dr Welch, king's NHS Healthcare Trust, Kings College Hospital; Dr Barbara, St Bartholomew's Hospital
ham Road Hospital, Guildford.

Trent
Dr Kinghorn, Royal Hallamshire Hospital, Sheffield; Dr Gupta, Scunthorpe General Hospital; Dr Fisk, Leicester Royal Infirmary; Dr Fraser, Chesterfield and North Derbyshire Hospital, Chesterfield; Dr Clay, Pilgrim Hospital, Boston.
West Midlands

Dr Joseph, Manor Hospital, Walsall; Dr Natin, Stratford upon Avon Hospital; Dr Murray, Burton District Hospital, Burton on Trent; Dr Wade, Coventry and Warwickshire Hospital, Coventry.

1 Simms I, Hughes G, Swan AV, et al. New cases seen at genitourinary medicine clinics: England 1996. Comm Dis Rep 1998;8 (Suppl 1):S1-11.

2 Hughes G, Simms I, Rogers PA, et al. New cases seen at genitourinary medicine clinics: England 1997. Comm Dis genitourinary medicine clinics:
Rep 1998;8 (Suppl 7):S1-11.

3 Carne CA, Weller IVD, Johnson AM, et al. Prevalence of antibodies to human immunodeficiency virus, gonorrhoea rates, and changed sexual behaviour in homosexual men in London. Lancet 1987;i:656-8.

4 Catchpole MA. Sexually transmitted diseases in England and Wales: 1981-1990. Com Dis Rev 1992;2:R1-7.

5 Gellan MCA, Ison CA. Declining incidence of gonorrhoea in London: a response to fear of AIDS? Lancet 1986;ii:920.

6 Weller IVD, Hindley DJ, Adler MW, et al. Gonorrhoea in homosexual men and media coverage of the acquired immune deficiency syndrome in London 1982-3. BMF 1984;289:1041.

7 Department of Health. Health of the nation: a strategy for health in England and Wales. London: HMSO, 1992. (Cm 1986.)

8 Lacey C, Merrick DW, Bensley DC, et al. Analysis of the sociodemography of gonorrhoea in Leeds, 1989-93. BMF 1997;314:1715-8.

9 Low N, Dakar-White, Barlow D, et al. Gonorrhoea in inner London: results of a cross sectional study. BMF 1997;314: 1719-23

10 Hughes G, Catchpole M. Surveillance of sexually transmitted infections in England and Wales. Eurosurveillance 1998; 3:61-5.

11 Office for National Statistics. Mid-1996 population estimates for England and Wales, Series PP1. London: HMSO, 1997.

12 Office for Population Censuses and Surveys. 1991 Census. Ethnic group and country of birth, Great Britain. London: HMSO, 1993.

13 Ethnicity in the 1991 census: demographic characteristics of the ethnic minority populations. Volume 1. Coleman, Salt, eds. Office for National Statistics. London: Stationery Office, 1996.

14 Johnson AM, Wadsworth J, Wellings K, et al. Sexual attitudes and lifestyles. Oxford: Blackwell Scientific Publications, 1994

15 Stata statistical software:Release 6.0 College Station. TX, USA: Stata Corporation, 1999

16 Rothenberg RB, Scarlett M, del Rio C, et al. Oral transmission of HIV. AIDS 1998;12:2095-105.

17 Unlinked Anonymous HIV Surveys Steering Group. Prevalence of HIV in England and Wales in 1997. Annual Report of the Unlinked Anonymous Prevalence Monitoring Programme (Chairman: J Metters). London: Department of Health, Public Health Laboratory Service, Institute of Child Health, 1998.

18 Fenton K, Johnson A, Nicoll A. Race, ethnicity and sexual health. BMF 1997;314:1703-4.

19 Barlow D, Daker-White G, Band B. Assortative sexual mixing in a heterosexual clinic population-a limiting factor in 7;11:1041-6.

20 Mares P, Henley A, Baxter C. Health care in multicultural Britain. Cambridge: Health Education Council and National Extension College, 1985.

21 CDSC. Sexually transmitted diseases quarterly report: gonorrhoea in England and Wales. Commun Dis Rep CDR Wkly 1998;8:194-6.

22 Bignell C. Antibiotic treatment of gonorrhoea - clinical evidence for choice. Genitourin Med 1996;72:315-20.

23 Evans BG, Catchpole MA, Heptonstall MA, et al. Sexually transmitted diseases and HIV-1 infection among homosexual men in England and Wales. BMF 1993;306:426-8.

24 Nicoll A, Catchpole M, Cliffe S, et al. Sexual health of teenagers in England and Wales. BMF 1999;318:1321-2.

25 Rothenberg RB, Potterat JJ. Temporal and social aspects of . Dis 1988;15:88-92. 


\section{LETTERS TO THE EDITOR}

\section{Successful treatment of recalcitrant condyloma with topical cidofovir}

EDITOR,-Despite the high prevalence of condylomata acuminata, their treatment remains unsatisfactory for both patients and physicians. Epidemiological studies estimated the prevalence of genital warts between $1-31 \%$ with a peak occurring in young adults. ${ }^{1}$ As a consequence, the economic burden of human papillomavirus (HPV) infection in the United States is estimated to exceed $\$ 8.5$ billion per year. ${ }^{2}$ Current treatments rely on the ablation of warts (cryotherapy, laser vaporisation, electrodissection, or trichloroacetic acid) or the interruption of cell division (podophylox, intralesional or systemic interferon, and 5-fluorouracil). Recently, imiquimod has been successfully used as a topical immune response modifier for the treatment of external anogenital warts. However, there remains a substantial number of patients who fail to respond to traditional and newer drugs. We report on such a patien with recalcitrant condylomata acuminata on the glans and shaft of the penis who was successfully treated using the novel virustatic cidofovir as a $1.5 \%$ gel.

A 48 year old man with a $2^{1 / 2}$ year history of condylomata acuminata had received laser treatment, podophylox, and imiquimod. The patient's history was remarkable for diabetes mellitus. He presented with numerous, flesh coloured, flat topped papules in a circular manner on the outer preputium and the glans, whereas some lesions in the coronary sulcus had a more verruciform appearance (fig 1). On histological analysis, the typical picture of acanthosis, papillomatosis, and numerous koilocytes was seen. Papillomavirus typing revealed HPV-43 by nested PCR using consensus primers.

Cidofovir was evaluated in the indicator patient at $1.5 \%$ cidofovir in a viscous gel (propylene glycol, parabene). Initially, the patient was treated on an outpatient basis with two applications of cidofovir gel per week to the respective lesions without any side effects. Thereafter, the patient was instructed to apply the gel three times a week by self application. At week 6 the patient pre-

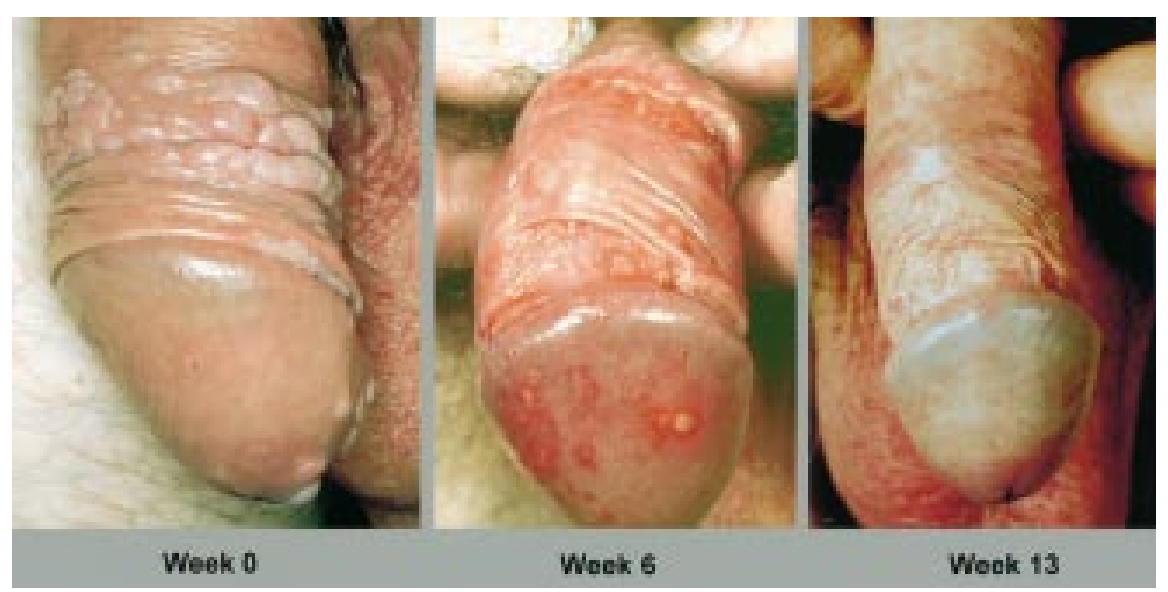

Figure 1 Condylomata acuminata with some lesions in the coronary sulcus having a more verruciform appearance. marked erythema on all treated sites (fig 1). The lesions were painful. Condylomata were still present in the coronary sulcus. At this point treatment was stopped and antiseptic treatment was given with betadine solution once daily. Seven weeks later (week 13) all lesions had completely healed (fig 1). Neither scarring nor dysaesthesia were noted. No recurrence has occurred since. Cidofovir, 1-[(S)-3-hydroxy-2-(phosphono-methoxy)propyl]cytosine, is a member of a new class of antiviral agents (phosphonylmethylether nucleotide analogues). ${ }^{5}$ It shows potent in vitro activity against a broad spectrum of herpesviruses, including human cytomegalovirus (CMV), HSV-1 and HSV-2, and adenovirus. Recent in vitro and in vivo studies have demonstrated activity against papillomavirus and poxvirus. $^{6}$

Cidofovir is a nucleotide analogue of deoxycytidine monophosphate (dCMP). Analogous to the metabolism of dCMP to dCTP, cidofovir is converted to the active cidofovir diphosphate that inhibits viral DNA polymerases. $^{8}$ The uptake of cidofovir into cells is slow, but the intracellular half life of the various metabolites is between 6 and 87 hours, thus allowing infrequent dosing. Compared with the general mechanism of activation of ganciclovir, which requires phosphorylation by the virus encoded UL97 gene, cidofovir does not depend on viral infection for its phosphorylation and can therefore prime cells to an antiviral state (prophylaxis).

The metabolism of cidofovir is negligible, since the majority $(>80 \%)$ is recovered unchanged in the urine. The principal systemic toxicity (nephrotoxicity) can be avoided by topical application.

This initial case report suggests that topical cidofovir may represent a valuable addition to the armamentarium of hard to treat condyloma. However, a careful evaluation of the dose and frequency of cidofovir application is warranted.

U R HENGGE

Department of Dermatology and Venerology, University of Essen, Hufelandstrasse 55, 45122 Essen, Germany G TIETZE Hospital Pharmacy, University of Essen, Hufelandstrasse 55, 45122 Essen, Germany

Correspondence to: U R Hengge

dermatology@uni-essen.de

1 Koutsky L. Epidemiology of genital huma papillomavirus infection. Am 7 Med 1997; 02:3-8.

sented with small erosions surrounded by a 
Table 1 Patient details

\begin{tabular}{|c|c|c|c|c|c|c|c|c|}
\hline $\begin{array}{l}\text { Patient } \\
\text { No }\end{array}$ & $\begin{array}{l}\text { Age } \\
\text { (years) }\end{array}$ & Smoker & $\begin{array}{l}\text { Referral } \\
\text { source }\end{array}$ & $\begin{array}{l}\text { Referral } \\
\text { diagnosis }\end{array}$ & Presenting features & $\begin{array}{l}\text { Urine } \\
\text { dipstick }\end{array}$ & $\begin{array}{l}\text { Urine } \\
\text { cytology }\end{array}$ & Diagnosis and treatment \\
\hline 1 & 26 & NR & GP & ?Infection & $\begin{array}{l}3 \text { months intermittent } \\
\text { painless haematuria }\end{array}$ & $\begin{array}{l}\text { Blood +ve } \\
\text { (trace) }\end{array}$ & $\mathrm{ND}$ & $\begin{array}{l}\text { Well differentiated bladder papillary TCC; } \\
\text { non-invasive; resected }\end{array}$ \\
\hline 2 & 34 & Yes & GP & ?Urethritis & $\begin{array}{l}6 \text { weeks frequency, } \\
\text { dysuria }\end{array}$ & Blood +ve & ND & $\begin{array}{l}\text { Poorly differentiated adenocarcinoma; bladder calculus } \\
\text { also present; tumour resection, chemotherapy, and } \\
\text { radiotherapy }\end{array}$ \\
\hline 3 & 53 & No & GP & $\begin{array}{l}\text { Recurrent } \\
\text { prostatitis }\end{array}$ & $\begin{array}{l}1 \text { year penile and } \\
\text { suprapubic pain; } \\
\text { frequency, dysuria }\end{array}$ & Blood +ve & Malignant & $\begin{array}{l}\text { Extensive transitional cell carcinoma in situ, involving } \\
\text { prostatic urethra; cystoprostatectomy }\end{array}$ \\
\hline 4 & 42 & No & GP & $\begin{array}{l}\text { Sterile pyuria } \\
\text { ?cause }\end{array}$ & $\begin{array}{l}1 \text { year penile and } \\
\text { perineal pain, } \\
\text { frequency, dysuria }\end{array}$ & $\begin{array}{l}\text { Blood +ve } \\
\text { (trace) }\end{array}$ & Malignant & $\begin{array}{l}\text { Extensive TCC plus carcinoma in situ, involving } \\
\text { prostatic urethra; cystoprostatectomy }\end{array}$ \\
\hline 5 & 50 & Yes & GP & ?Infection & $\begin{array}{l}6 \text { weeks frequency, } \\
\text { urgency, dysuria }\end{array}$ & Blood +ve & Suspicious & $\begin{array}{l}\text { Poorly differentiated TCC at bladder neck; muscle } \\
\text { invasion; cystoprostatectomy, and chemotherapy }\end{array}$ \\
\hline
\end{tabular}

$\mathrm{NR}=$ not recorded $\mathrm{ND}=$ not done $; \mathrm{TCC}=$ transitional cell carcinoma.

genitourinary infection, rather than suspected neoplasia, because of his young age (26 years).

Bladder neoplasia is especially liable to cause irritative symptoms when represented by, or associated with, carcinoma in situ of the bladder urothelium. ${ }^{12}$ Urine cytology may be useful in this subgroup, and was abnormal in all three of the five patients in whom it was requested. When this process involves the prostatic urethra, symptoms mimicking prostatitis may arise. Early diagnosis of bladder neoplasia is of prognostic importance; the presence of carcinoma in situ or prostatic involvement by bladder carcinoma are poor prognostic features for which radical surgery may be required. ${ }^{14}$

These cases highlight the importance of careful follow up of patients presenting with persistent irritative-type bladder symptoms, especially in an older age group, when specific tests for genitourinary infection are negative, and where microscopic haematuria is a feature. Bladder carcinoma should be considered in this subgroup; urine cytology and referral for cystourethroscopy may be indicated. Although rare in younger adult males, bladder cancer should not be ruled out in men under the age of 45 years, and our experience strengthens the case for continuing with routine urine testing in genitourinary medicine clinics.

G A LUZZI

South Buckinghamshire NHS Trust, Wycombe Hospital, High Wycombe, HP11 2TT and Oxford Radcliffe NHS Trust, Radcliffe Infirmary, Oxford $O X 26 H E$ A EDWARDS

Oxford Radcliffe NHS Trust, Radcliffe Infirmary,

Correspondence to: Dr Luzzi

1 Messing EM, Catalona W. Urothelial tumors of the urinary tract. In: Walsh PC, Retik AB, Vaughan ED, Wein AJ, eds. Campbell's urology. 7th ed. Philadelphia: WB Saunders, 1998:2327-410.

2 Hamilton M. Cancer of the bladder presenting as "cystitis" or "prostatism". Med f A Aust 1969, 2:89-91.

3 Luzzi GA, Cranston D. Bladder carcinoma presenting as prostatitis syndrome. Br f Urol Int 2000;85:774-5.

4 Solsona E, Iborra I, Ricos JV, et al. The prostate involvement as prognostic factor in patients with superficial bladder tumours. $\mathcal{f}$ Urol with superficial blad.

Accepted for publication 25 February 2000

\section{Atrial myxoma and HIV infection}

EDITOR,-Atrial myxoma has not previously been reported in HIV infection. We describe a patient with advanced HIV disease who underwent surgery for this condition.
The patient was diagnosed with asymptomatic HIV infection in February 1987 when she was aged 50 years. Her CD4 count was $690 \times 10^{6} / 1$ at this time. HIV infection was acquired through sexual intercourse with a bisexual male partner. In December 1990 the CD4 lymphocyte count had fallen to 190 $\times 10^{6} / 1$ and zidovudine monotherapy was started. This was continued until 1996 when she was prescribed a combination regimen. Co-trimoxazole was given for Pneumocystis carinii prophylaxis, but the patient deferred starting this until December 1992.

In February 1992 the patient was admitted to another hospital with an acute myocardial infarction which was successfully thrombolysed. Fasting lipids were within the normal range. There were no cardiac risk factors apart from smoking.

In September 1995 the patient experienced a syncopal episode. An echocardiogram revealed a mass in the left atrium consistent with a left atrial myxoma. A coronary angiogram showed normal coronary arteries. Surgical resection of the myxoma was recommended.

In December 1995 the patient's CD4 count was $64 \times 10^{6} / 1$, but apart from oral candidiasis there had been no HIV related problems since diagnosis. Two leading UK HIV physicians were asked if they considered surgery to be advisable. They estimated the patient's likely survival from HIV disease to be 1-4 years. The risks of major heart surgery had to be balanced against the likelihood of recurrent symptoms from the myxoma in the next $1-4$ years. The patient and her physician agreed to proceed with surgery.

On 4 December 1995 the patient underwent surgical resection of a pedunculated left atrial mass. Histological examination confirmed a benign atrial myxoma. The procedure was uncomplicated and she was discharged from hospital 4 days later. Annual cardiac review including an echocardiogram has shown no evidence of recurrence up to the present time. She remains free from cardiovascular symptoms. Her HIV disease is managed with combination therapy that consists of stavudine, lamivudine, and efavirenz. Current CD4 count is $564 \times 10^{6} / 1$ and viral load less than 50 copies/ml (Chiron bDNA v3.0)

Atrial myxoma is a rare tumour that is considered to be benign although recurrence and metastases have been described. ${ }^{1}$ The myocardial infarction suffered by our patient may have been an embolic manifestation of the myxoma, and the normal serum lipids and normal coronary angiogram almost 4 years later would support this.

In 1995 expert opinion provided a very guarded prognosis for someone with a CD4 count of $60 \times 10^{6} / 1$ who had been exposed to a single antiretroviral agent, zidovudine. Today there would be less debate over the merits of such a surgical procedure in this scenario, and this case demonstrates the excellent outcome that can be achieved with major surgery despite profound immunosuppression. The proved benefits of HAART (highly active antiretroviral therapy) have made it unacceptable to deny major surgical interventions to individuals with HIV.

ANDREW J SHAW KEN A MCLEAN Department of Genitourinary Medicine, Charing Cross Hospital, Fulham Palace Road, London W6 8RF

Correspondence to: Dr Andrew Shaw, Department of Genitourinary Medicine, Northwick Park Hospital, Watford Road, Harrow, Middlesex HA1 3UJ

1 Desousa AL, Muller J, Campbell RL, et al. Atrial myxoma: a review of the neurological complications, metastases, and recurrences. $f$ Neuro Neurosurg Psychiatry 1978;41:1119-24.

Accepted for publication 25 February 2000

\section{The association between receptive} cunnilingus and bacterial vaginosis

EDITOR,-We are puzzled by the surprisingly little, if any, serious work done to explain the epidemiological enigma of high prevalence of bacterial vaginosis (BV) in lesbians, ${ }^{1}$ and the oft observed, but as yet unconfirmed association between $\mathrm{BV}$ and receptive cunnilingus in women in general.

In a detailed study of 17 consecutive lesbians attending the department of genitourinary medicine at the Royal Sussex County Hospital in Brighton, bacterial vaginosis was found in six women $(35 \%)$. Of nine lesbians who practised receptive cunnilingus in the previous 4 weeks, six (67\%) had BV. By contrast, no BV was present in all eight women who did not practise oral sex (table 1).

In a parallel prospective study of 256 consecutive heterosexual female patients attending the same department, $55(21 \%)$ were diagnosed as having BV. Of 111 women who practised receptive cunnilingus in the previous 4 weeks, 41 (37\%) had BV. Of 145 women who did not have oral sex, only 14 $(10 \%)$ had BV (table 1$)$. In both groups there was strong association between $\mathrm{BV}$ and receptive cunnilingus $(\mathrm{p}<0.001)$.

The evidence associating bacterial vaginosis with oral sex is too strong to be ignored and repeatedly dismissed. The mouth is full of Gram positive and Gram negative organisms including Bacteroides oralis and, albeit in much smaller quantities, lactobacilli. These organisms are part of normal flora in the mouth, but are they normal to the vagina? Might the tiny amount of lactobacilli be enough to act as a phage which destroys the 
Table 1 BV prevalence results

\begin{tabular}{lcc}
\hline Lesbians & No of women & BV diagnosed \\
\hline Total & 17 & $6(35 \%)$ \\
Practised receptive cunnilingus in previous 4 weeks & 9 & $6(67 \%)$ \\
Did not practise receptive cunnilingus & 8 & 0 \\
\hline Heterosexual women & No of women & BV diagnosed \\
\hline Total & 256 & $55(21 \%)$ \\
Practised receptive cunnilingus in previous 4 weeks & 111 & $41(37 \%)$ \\
Did not practise receptive cunnilingus in past 4 weeks & 145 & $14(10 \%)$ \\
\hline
\end{tabular}

endogenous healthy vaginal lactobacillus? In an interesting hypothesis, Blackwell described the possible effect of biochemical and microbial abnormalities in the vagina on BV recurrence. ${ }^{2}$ She also quoted Berger's description of concordant vaginal floras in lesbian couples, suggestive of a mechanical transfer of an infectious agent. ${ }^{3}$ Is it not possible for mouth organisms or hostile salivary enzymes to induce biological and microbial abnormalities in the vagina?

Furthermore, mechanical transfer of infectious agents in lesbian couples is most likely to occur via cunnilingus, a not uncommon practice among lesbians.

Cunnilingus is a common fact of sexual life. The dynamics of this practice vary considerably. If association between $\mathrm{BV}$ and oral sex is ever confirmed, would the degree of tongue penetration be a factor and should it be incorporated in the aetiology equation? Further and more extensive studies are certainly indicated.

S E TCHAMOUROFF S K PANJA

Department of Genitourinary Medicine, Royal Sussex County Hospital, Brighton BN2 5BE

Correspondence to: Dr Tchamouroff

1 McCaffrey M, Varney PA, Evans B, et al. A study of bacterial vaginosis in lesbians. Int $\mathcal{F}$ STD AIDS 1997;8(Suppl 1):11.

2 Blackwell AL. Vaginal bacterial phaginosis? Hypothesis. Sex Transm Inf 1999;75:352-3.

3 Berger BJ, Kolton S, Zenilman JM, et al. BacteBerger BJ, Kolton S, Zenilman JM, et al. Bacte-
rial vaginosis in lesbians: a sexually transmitted rial vaginosis in lesbians: a sexually trans
disease. Clin Infect Dis 1995;21:1402-5.

Accepted for publication 25 February 2000

\section{Is partner notification in the public} interest?

EDITOR,- This ethical debate ${ }^{1}$ calls for comment.

Why did the clinicians only suspect AIDS? Surely at the second attendance the diagnosis was clinically obvious. As well as continuing treatment of candidiasis and starting prophylaxis of Pneumocystis carinii pneumonia, was not treatment for AIDS indicated? For fear of court proceedings a specimen of blood untested or surplus to routine haematological tests could have been stored to confirm, if necessary, the clinical diagnosis. A perspicacious defence lawyer could make much of this in terms of doctor thoroughness, cautiousness, and thoughtfulness - on behalf of his client.

In terms of contact tracing the word "disclosure" occurs repeatedly. Surely the first thing an index case is told when his/her cooperation is sought is that under no circumstances will their name be divulged. The contacts, when attending, will be refused any information regarding who has named them and immediately assured that the same confidentiality will be maintained if their cooperation is called for in the contact tracing process.
Only when it becomes widely known in a clinic that such confidentiality is thoroughly pursued will counterproductive fears be eliminated. With understanding and cooperation it can be done.

SAKINA RASHID

Department of Genito-Urinary Medicine, Sunderland Royal Hospital, Kayll Road, Sunderland SR4 7TP

1 Winter AJ, Mullis D, Radcliffe KW, et al. Is partner notification public interest? Sex Transm Inf 1999;75:354-7.

\section{Sexual partner reduction and HIV infection}

EDITOR,- We recently conducted a national urban random sample survey of 1400 men of sexually active age in the Dominican Republic to measure possible change in sexual behaviour. This sexual behaviour change (SBC) survey was prompted by results from the 1996 demographic and health survey, which found that $84.8 \%$ of a national random sample of Dominican men claimed that they had changed their behaviour in some way because of their fear of, or concern about, AIDS. The proportion of respondents reporting behaviour change such as becoming monogamous or reducing their number of sexual partners was about triple the proportion reporting condom adoption. In our SBC survey, $79 \%$ of respondents claimed to have changed behaviour because of concern about AIDS. A majority $(52.2 \%)$ said they had become monogamous or reduced their number of sexual partners. This was followed by condom adoption (14.6\%), only having sexual relations with a person they know (13.9\%); avoiding relations with "prostitutes" $(9.0 \%)$ or becoming abstinent (1.6\%). A small proportion $(2.8 \%)$ had not yet begun to have sexual relations. As with the Dominican DHS findings, we see that most answers are classifiable as behaviour change, as distinct from condom adoption. This follows a pattern found in recent studies in countries such as Uganda and Zambia. A recent review of findings from behavioural change surveys in 16 countries in Africa, Latin America, and the Caribbean shows that partner reduction is more often reported than condom adoption. If sizeable numbers of men reduce their number of sexual partners, can this have significant impact on HIV infection rates? Urban HIV seroprevalence among the general or low risk Dominican population seems to have stabilised at the $1.9-2.0 \%$ level since 1995, according to the US Census Bureau. Recent studies that have modelled the impact of different interventions on HIV infection rates in east Africa suggest that reduction in number of partners can have a great impact on averting HIV infections, in fact greater than either condom use or treatment of STDs. ${ }^{23}$ Of course, impact of partner reduction on HIV infection rates would be espe- cially strong where there is relatively high HIV seroprevalence among potential partners. In view of these modelling studies as well as population based surveys such as the two cited from the Dominican Republic, perhaps there ought to be greater equity in resource allocation between HIV/AIDS prevention programmes promoting behaviour changesuch as monogamy/fidelity or at least reduction of number and frequency of change of sex partners - and far more familiar programmes that promote and provide condoms.

EDWARD C GREEN ALDO CONDE

2807 38th Street, NW Washington, DC 20007, USA Correspondence to: Dr Green

1 Gardner R, Blackburn RD, Upadhyay UD. Closing the condom gap. Population Reports, Series $H$. Baltimore: Johns Hopkins University, April 1999.

2 Bernstein RS, Sokal DC, Seitz ST, et al. Simulating the control of a heterosexual HIV epidemic in a severely affected east African city.

3 Robinson NJ, Mulder DW, Auvert B, et al. Modelling the impact of alternative HIV intervention strategies in rural Uganda. AIDS 1995;9: 1263-70.

Accepted for publication 25 February 2000

Features of AIDS and AIDS defining diseases during the highly active antiretroviral therapy (HAART) era, compared with the pre-HAART period: a case-control study

EDITOR,-To assess the features of AIDS defining illnesses during the HAART era versus those observed before the introduction of HAART, the characteristics of 72 consecutive patients, diagnosed in 1997-9, were compared with those of 144 subjects randomly selected from the 436 patients diagnosed from 1985 to 1995 , in a case-control study.

An impressive drop in AIDS diagnosis was seen shortly after the introduction of HAART, with only 38,21 , and 13 cases per $\sim 1000$ patient years observed in 1997, 1998, and 1999 respectively, versus a mean frequency $>60$ cases per $\sim 1000$ patient years, demonstrated during 1991-5. A tendency towards an increased incidence of female sex was shown in 1997-9 compared with 1985-95 (33.3\% versus $27.1 \%)$, together with a rise of mean CD4+ lymphocyte count (86.8 (SD 99.4) versus 72.1 (93.7) cells $\times 10^{6} / 1$ ), while an increase in the mean patient age was highly significant $(39.8$ (8.3) versus 34.6 (7.7) years; $p<0.0001)$. When considering the exposure to HIV infection, drug abuse became significantly less important in the HAART era $(p<0.05)$, while heterosexual transmission was notably increased $(34.7 \%$ versus $13.2 \%$ of cases; $\mathrm{p}<0.0003)$. The distribution of AIDS defining disorders during the HAART era showed an tendency to a reduction in cytomegalovirosis, cryptococcosis, mycobacteriosis, cryptosporidiosis, and HIV encephalopathy, while a relative increase in pneumocystosis, oesophageal candidiasis, wasting syndrome, tuberculosis, and non-Hodgkin's lymphoma was found; neurotoxoplasmosis and Kaposi's sarcoma were stable (table 1). However, while pneumocystosis, Candida oesophagitis, neurotoxoplasmosis, and Kaposi's sarcoma represented the four most frequent AIDS related events in both study periods, cytomegalovirosis, HIV encephalopathy, cryptococcosis, and mycobacteriosis (which ranked fifth to eighth in 
Table 1 AIDS defining events and mean CD4+ lymphocyte count at disease occurrence, in the two considered time periods

\begin{tabular}{|c|c|c|c|c|}
\hline \multirow[b]{2}{*}{ AIDS defining diseases } & \multicolumn{2}{|c|}{$\begin{array}{l}\text { Years } 1985-95 \\
\text { (144 patients, } 151 \text { diseases) }\end{array}$} & \multicolumn{2}{|c|}{$\begin{array}{l}\text { Years } 1997-9 \\
\text { ( } 72 \text { patients, } 76 \text { diseases) }\end{array}$} \\
\hline & $\begin{array}{l}\text { No of } \\
\text { diseases } \\
(\%)\end{array}$ & $\begin{array}{l}\text { Mean CD4+ } \\
\text { count (cells } \\
\left.\times 10^{6} / l(S D)\right)\end{array}$ & $\begin{array}{l}\text { No of } \\
\text { diseases } \\
(\%)\end{array}$ & $\begin{array}{l}\text { Mean CD4+ } \\
\text { count (cells } \\
\left.\times 10^{6} / l(S D)\right)\end{array}$ \\
\hline Pneumocystis carinii pneumonia & $40(26.5)$ & $58.6(49.0)$ & $22(28.9)$ & $62.4(72.1)$ \\
\hline Oesophageal candidiasis & $21(13.9)$ & $71.3(62.6)$ & $16(21.0)$ & $129.9(98.1)$ \\
\hline Neurotoxoplasmosis & $17(11.3)$ & $79.9(62.1)$ & $9(11.8)$ & $75.6(39.2)$ \\
\hline Kaposi's sarcoma & $15(9.9)$ & $98.1(101.3)$ & $7(9.2)$ & $133.3(68.3)$ \\
\hline Cytomegalovirus (retinitis or disseminated disease) & $10(6.6)$ & $77.3(100.2)$ & $1(1.3)$ & 48 \\
\hline HIV encephalopathy (AIDS-dementia complex) & $7(4.6)$ & $81.1(45.9)$ & $2(2.6)$ & $102.0(29.7)$ \\
\hline Extrapulmonary cryptococcosis & $6(4.0)$ & $25.2(19.4)$ & $0(-)$ & - \\
\hline Disseminated mycobacteriosis & $5(3.3)$ & $62.4(50.5)$ & $1(1.3)$ & 78 \\
\hline Wasting syndrome & $5(3.3)$ & $38.4(41.1)$ & $5(6.6)$ & $121.2(54.0)$ \\
\hline \multicolumn{5}{|l|}{ Non-Hodgkin's lymphoma or primary CNS } \\
\hline lymphoma & $5(3.3)$ & $116.3(41.1)$ & $4(5.3)$ & $125.9(71.2)$ \\
\hline Cryptosporidiosis & $4(2.7)$ & $38.3(10.2)$ & $0(-)$ & - \\
\hline Tuberculosis (pulmonary or disseminated disease) & $3(2.0)$ & $148.2(51.4)$ & $5(6.6)$ & $289.3(71.2)$ \\
\hline Other AIDS defining events & $13(8.6)$ & $55.3(48.9)$ & $4(5.3)$ & $73.3(101.1)$ \\
\hline
\end{tabular}

frequency during the pre-HAART era), virtually disappeared after the introduction of HAART (28 versus four overall cases; $\mathrm{p}<0.007)$, together with cryptosporidiosis. Neoplasms and HIV related disorders (encephalopathy and wasting syndrome), showed a slightly increased frequency during the HAART era $(16.8 \%$ and $9.2 \%$ during $1997-9$, versus $13.2 \%$ and $7.9 \%$ respectively, during the pre-HAART period). A considerable trend to increased mean CD4+ coun was found during the HAART era for all AIDS related illnesses considered, except neurotoxoplasmosis. However, this increase in CD4+ count was significant only for Candida oesophagitis $(\mathrm{p}<0.04)$, wasting syndrome $(p<0.03)$, and tuberculosis $(p<0.03)$ probably because of small patient samples. Only seven of the 72 patients who developed AIDS since 1997 (9.7\%), were effectively treated with HAART for more than 3 months before diagnosis; in the remaining 65 cases HIV infection was detected concurrently with an AIDS defining event in subjects who were unaware of their condition (40 cases), or refused HAART or carried out it with poor adherence (25 patients).

Although a sharp decline in the incidence of multiple AIDS defining events was demonstrated since the introduction of HAART, the distribution of primary AIDS associated diseases showed limited modifications..$^{1-3}$ An increased incidence of women, a higher patient age, a greater role for heterosexual transmission compared with injecting drug addiction, and a rise in CD4+ count were disclosed by us in the HAART era compared with the pre-HAART period. Appreciable modifications of the spectrum of AIDS associated illnesses were also observed during the HAART era (a drop of cytomegalovirosis, cryptococcosis, mycobacteriosis, cryptosporidiosis, and HIV encephalopathy, with a parallel increase in pneumocystosis, oesophageal candidiasis, wasting syndrome, tuberculosis, and non-Hodgkin's lymphoma), together with a considerable trend towards an increased mean CD4+ count at diagnosis, as previously noted. ${ }^{25}$ Disorders which are directly or indirectly associated with HIV damage itself, AIDS related neoplasms, and opportunistic diseases occurring with a less profound immunodeficiency, show a substantially stable or even increasing incidence among newly diagnosed cases of AIDS. ${ }^{12}$ However, opportunistic diseases related to a severe immunodeficiency are still frequen among AIDS defining events, since the majority of cases identified during the
HAART era occur in patients who are not early detection and aggressive treatment of HIV infection may definitively improve the epidemiology of AIDS; a continued surveillance of AIDS related disorders remains critical for the implementation of therapeutic and prophylactic strategies.

ROBERTO MANFRED FRANCESCO CHIODO Department of Clinical and Experimental Medicine, Division of Infectious Diseases, University of Bologna, Bologna, Italy

Correspondence to: Dr Roberto Manfredi, Department of Clinical and Experimental Medicine, Division of Infectious Diseases, University of Bologna, S Orsola Hospital, Via Massarenti, 11, I-40138 Bologna, Italy

1 Palella FJ, Delaney KM, Moorman AC, et al. Declining morbidity and mortality among patients with advanced human immunodeficiency virus infection. $N$ Engl $\mathcal{F} \mathrm{Med}$ 1998;338:853-60.

2 Forrest DM, Seminari E, Hogg RS, et al. The incidence and spectrum of AIDS-defining illnessess in persons treated with antiretrovira drugs. Clin Infect Dis 1998;27:1379-85.

3 Mocroft A, Sabin CA, Youle M, et al. Changes in AIDS-defining illnessess in a London Clinic, Retrovirol 1999;21:401-7.

4 Franceschi S, Dal Maso L, la Vecchia C. Advances in the epidemiology of HIVAdvances in the epidemiology of HIVassociated non-Hodgkin's lymphoma and
other lymphoid neoplasms. Int $\mathcal{F}$ Cancer 1999; other lymp.

5 Law MG, De Winter L, McDonald A, Cooper DA, Kaldor JM. AIDS diagnoses at highe CD4 counts in Australia following the introduction of highly active antiretroviral treatment. AIDS 1999;13:263-9.

Accepted for publication 25 February 2000

\section{BOOK REVIEWS}

Hustling for Health. Developing Services for Sex Workers in Europe. Pp 83; Price 10 euros. The European Network for HIV/ STD Prevention in Prostitution (EUROPAP/TAMPEP), 1998. Contact Judith Kilvington/Helen Ward, Coordinating Centre, European Network for HIV/STD Prevention in Prostitution, Department of Epidemiology and Public Health, Imperial College School of Medicine, London W2 1PG (tel: 0207594 3315; fax: 0207402 aware of their disease, or fail HAART. Only 1987-1998. f Acquir Immune Defic Syndr Hum
2150; email: europap@ic.ac.uk). (Also available in nine other European languages (Danish, Finnish, Flemish, French, German, Greek, Italian, Portuguese, Spanish), and the full text (without illustrations) can be found online on the website (http://www.med. ic.ac.uk/df/dfhm/europap/hustling/press.htm).

How do you begin to address the sexual health needs of commercial sex workers (CSWs)? Here you will find (most of) the answers. This immensely practical book is essential for those setting up an outreach service, or simply wishing to know more about commercial sex work. It is the outcome of a series of projects and workshops, written by workers providing services to CSWs throughout Europe, and draws from the lessons learnt by these pioneering workers and clients. It is written with great clarity and frankness. The A4 layout is bold, imaginative, and attractive, with illustrations of promotional literature. Its European inclusiveness means that sadly it cannot be specific regarding, for example, the law as it applies to commercial sex. It does, however, give the broad framework with which providers must acquaint themselves wherever they work. It takes us through the steps; sources of funding, the scope of the service, useful contacts, where to make contact with CSWs, and so on. Importantly, in the current climate there are sections on evaluation and monitoring of the service, the legal and political context of the work, and dealing with the media. It stresses the heterogeneous nature of commercial sex workers whether male, female, or transsex, and the spectrum of commercial sex venues. Peer educator programmes are covered in some detail.

There are fascinating pieces of practical advice-for example, cooperate with police, but don't be identified too closely with law enforcement. Advising police of your outreach vehicle's registration number may prevent you being stopped for kerb crawling!

You can set up a flawless screening service and find only a few CSWs attend. The book reminds us middle class, health aware professionals that, for many, sexual health is not a priority. We are perplexed when faced with "indifference, hostility and self destructive behaviour"; that her next fix, a roof over her head, or the desire to have a baby might be more important to the CSW than the nebulous risk of HIV. Address some of these needs and you have the carrot to attract attention to and confidence in your service. The spin off is that clients can then benefit from STD screening and safer sex advice. Simply providing toilets and somewhere safe to have a cup of tea may be enough for some.

I would have liked to see a further reading list, but this book fulfils its remit excellently.

MARY STEVENSON

The Guest Hospital, Tipton Road, Dudley DY1 4SE

Children in Mind. Pp 106; $£ 20$. London: Audit Commission, 1999. ISBM 186240-8.

The Audit Commission, established in 1983, reports on a 2 year study of the specialist Child and Adolescent Mental Health Services (CAMHS) as provided by local authorities and NHS trusts. Local information has been processed centrally to generate facts and figures and comparative data. 
The 13000 bodies providing CAMHS spend $£ 100$ billion (sic) of public money annually in England and Wales. The Commission's team of seven have met with external advisers with a view to shaping of the audit, its comments, and guidance. The aim is to achieve economy with efficiency and effectiveness. The report is in five chapters and five helpful appendices. It lists 71 references and has an index.

Under the heading "The changing context" it is revealed that one in five children and adolescents (alas, not defined for females and males) suffer from a wide range of mental health problems of variable degrees of severity from social ineptitude through psychological to severe psychiatric disorder. Strong links are noted with juvenile crime, alcohol and drug abuse, eating disorders, and of course self harm.

The key components of the CAMHS are viewed as four "tiers": (a) Those providing primary intervention, eg, GPs, health visitors, residential social workers, juvenile justice workers, school nurses, and teachers (b) Professional providers of services, eg, clinical and educational psychologists, paediatricians, child psychiatric nurses in the community, and child psychiatrists. (c) High grade specialist services for severe, complex and persistent disorders, eg, child psychiatrists, community psychiatric nurses, psychotherapists, occupational therapists and art, music, and drama therapists. (d) Consists of hospital services especially unnamed "highly specialised outpatient teams". This clearly applies to accident and emergency departments, obstetric and gynaecology departments, and genitourinary medicine departments. These deal very adequately with self poisoning episodes, premarital abortions, and sexually acquired infection, but fail to see the underlying behaviour as but one manifestation of an ongoing complex of medicosocial pathology. Clearly, services for the care of our adolescents, unlike paediatrics and geriatrics, are seriously fractionated.

What follows should help the holistically minded hospital doctor to increase his awareness and skills and so make more regular and early use of referral routes and emergency cover arrangements provided by developing CAMHS.

It is clear that in many areas there is an urgent need to plan how best to meet unmet needs, including appropriate monitoring. The final chapter of this book purports to show how, with national support, highly active local coordination can establish and advance improvements. Recommendations are provided. There are opportunities for masterly leadership.

As the first specialty to be nationalised in the United Kingdom, genitourinary medicine has come a long way from the days of "pox doctoring" in "clap clinics". Has the time come for it to give a lead in the development of more appropriate and comprehensive services for adolescents?

For the long sighted and adventurous GU physician this book suggests how to begin.
Laboratory Diagnosis of Sexually Transmitted Diseases. Pp 135 (available in English, French, and Spanish); Sw fr 35/ $\$ 31.50$, in developing countries $\mathrm{Sw}$ fr 24.50 . Geneva: World Health Organisation, 1999. ISBN 9241545011 .

"Venereal diseases are like the fine arts-it is pointless to ask who invented them." (Voltaire, Dictionaire philosophique).

Sexually transmitted diseases (STDs) now rank among the top ten diseases for which adults in developing countries seek health care. The economic burden of STDs on both developed and developing countries is enormous. Infection with conventional STDs is a risk factor for transmission of infection with HIV, and therefore for the development and spread of the AIDS

It is imperative that laboratory services are available to guide the clinician to the correct diagnosis and treatment of these conditions, and to give an accurate epidemiological picture of their prevalence in a particular community in order to target relevant populations and ensure optimal and economic use of available resources. Yet, the availability of both funds and technology varies widely between different settings.

This manual sets out to give comprehensive guidance on tests available and applicable to the level of expertise and funding available.

Nine chapters cover the major STDs, encompassing bacterial and viral infections, and under the umbrella of vaginitis in adults; trichomoniasis, candidiasis, and bacterial vaginosis. Each chapter begins with a brief description of the microbiology of the infective agent and the clinical spectrum of disease. The detail given is not consistent, being comprehensive for chancroid and granuloma inguinale, and surprisingly brief for HIV and chlamydia by way of contrast. Then follows a description of collection and transport requirements, and of techniques for diagnosis. The emphasis is on tests that are possible in a reasonably well equipped laboratory, but not one capable of reference facilities. Tests that are suitable for use in the field are highlighted. An evaluation of sensitivity and specificity is also given. Other tests available in central or reference laboratories are mentioned in brief, usually with supporting references.

Two annexes cover media, reagents and stains, and details of equipment required to diagnose each condition. A third annex is an interesting table of which tests should be available at "peripheral," "intermediate," and "central" laboratories.

Overall, this manual is to be welcomed as an educational and reference source for medical microbiologists, technologists, and clinicians. However, I would recommend that the authors "road test" the manual to discover omissions in technical detail that would prevent the sole use of the manual in the field.

Indifferent colour reproduction detracts from the quality of the text-for example, blue reactions appearing as red in the figure.

For the next edition, a chapter on basic microscopical techniques and another on the general principles and interpretation of laboratory tests would provide useful introductions to an otherwise excellent publication. and Emergency Building, London WC1E 6DB

\section{CD-ROM REVIEWS}

Topics in International Health. HIV/ AIDS. London: The Wellcome Trust, $\mathrm{CAB}$ International, 1998. Institutional licence $£ 120$; individual licence $£ 30$

This is a superb CD Rom covering various aspects of HIV and AIDS by means of interactive tutorials. It is clear, concise, and up to date and has tutorials under the following headings: Overview, Biology of HIV, Natural history, Infections and malignancies, Epidemiology, Transmission and risk factors, Prevention, Diagnosis and monitoring, Women and children, Management, Social and psychological issues.

Each tutorial is self contained (which does lead to some duplication) and has self assessment questions - usually with click and drag matching of statements or true/false boxes. The information itself is well illustrated and contains animations and a video clip, together with further information/annotations in pop up boxes. At the end of each section there is a set of summary points, a reading list, and further activities such as internet sites.

There is a searchable picture index which allows you to search, view, and save sets of images for reference and lectures (although copyright does apply), and a glossary of terms.

Overall this is an excellent CD Rom providing good information, presented in an attractive and usable way, with a wealth of illustrations. I would strongly recommend it.

SARAH EDWARDS

Department of GU Medicine, West Suffolk Hospital, Bury St Edmunds, Suffolk, IP33 2QZ

Facing HIV: A Resource for Primary Healthcare. Contributors: Annalisa Rossi, Margaret Allen, Sirrka-Liisa Nurkkala, Begona Gros, Cristina Martinez-Bueno. £29.38. East Lancashire Health Authority, South Lancashire Health Authority, University of Central Lancashire, The Faculty of Health, and The Centre for Learning Technologies at the University of Central Lancashire

This is an interesting CD Rom which, gives a very personal guide to issues surrounding HIV - covering the experience of the patient, carer and healthcare professionals.

Four main sections cover the following areas: Living with HIV, Is HIV different? Loss, grieving and bereavement, Supporting people affected by HIV.

These areas are illustrated by short video clips and backed up by further information. Basic information is given about HIV treatment, the impact of diagnosis and of ill health, and other related topics. Unfortunately the information about drug treatment is already outdated and there is no search facility.

The strength of this CD Rom is the view it gives of the emotional responses to HIV and the strategies for coping with the infection from the viewpoint of those involved. The academic content is limited but it is worth a look for the patient perspectives. Bury St Edmunds, Suffolk, IP33 2QZ 


\section{NOTICES}

9th International Congress on Infectious Diseases, 9-12 April 2000, Buenos Aires, Argentina

Further details: International Society for Infectious Diseases, 181 Longwood Avenue, Boston, MA 02115, USA (tel: (617) 277 0551; fax: (617) 731-1541; email: isidbos@ aol.com).

Sexually Transmitted Diseases in a Changing Europe, 14-15 April 2000, Rotterdam, The Netherlands

Further details: Mediscon, Organisation for Medical Congresses, PO Box 113, 5660 AC Geldrop, Netherlands (tel: +31-(0)402852212; fax: +31-(0)40-2851966; email: MEDISCON@IAEhv.nl).

20th Scientific Conference of Venereological Section of the Polish Society of Dermatologists, Bialystok, 28-30 April 2000

The conference will be on epidemiological and clinical aspects of sexually transmitted infections. Further details: Dept Dermatology and Venereology, Sw Rocha 3, 15-879 Bialystok, Poland (tel/fax: (085) 7422778; email: bozchod@amb.ac.bialystok.pl).

Joint meeting of the MSSVD and the ASTDA, 3-7 May 2000, Baltimore Marriott Inner Harbor Hotel, Baltimore, Maryland, USA

Further details: Dr Keith Radcliffe, honorary assistant secretary, MSSVD (fax: +44(0) 121237 5729; email: k.w.radcliffe@bham.ac.uk).

Imperial College School of Medicine, Division of Paediatrics, Obstetrics, and Gynaecology, Advanced Course in Fetal Medicine, 22-24 May 2000

Further details: Symposium Office, Imperial College School of Medicine, Queen Charlotte's and Chelsea Hospital, Goldhawk Road, London W6 OXG (tel: 0208383 3904; fax: 0208383 8555; email: sympreg@ic.ac.uk).

Imperial College School of Medicine, Division of Paediatrics, Obstetrics, and Gynaecology, Advanced Course for $\mathrm{Ob}$ stetricians and Gynaecologists, 19-23 June 2000

Further details: Symposium Office, Imperial College School of Medicine, Queen Charlotte's and Chelsea Hospital, Goldhawk Road, London W6 OXG (tel: 0208383 3904; fax: 0208383 8555; email: sympreg@ ic.ac.uk).

Australasian Sexual Health Conference, Ven Troppo, Carlton Hotel, Darwin, Northern Territory, 21-24 June 2000

Further details: Shirley Corley, Conference manager, Dart Associates, PO Box 781, Lane Cove, 2066 NSW, Australia (tel: 029418 9396/97; fax: 0209418 9398; email: dartconv@mpx.com.au).

Imperial College School of Medicine, Division of Paediatrics, Obstetrics, and Gynaecology, Caring for Sexuality in Health and Illness (for healthcare professionals and nurses), jointly with Association of Psychosexual Nursing 27 June 2000
Further details: Symposium Office, Imperial College School of Medicine, Queen Charlotte's and Chelsea Hospital, Goldhawk Road, London W6 OXG (tel: 0208383 3904; fax: 0208383 8555; email: sympreg@ ic.ac.uk).

Sexual Health and HIV Conference: Facing the Millennium, Portsmouth Marriott Hotel, Portsmouth, 28 June 2000

Further details: Rebecca Mitchell (tel: 023 9286 6796; fax: 0239286 6769).

6th ESC Congress on Contraception in the Third Millennium: a (R)Evolution in Reproductive and Sexual Health, Ljubljana, Slovenia, 28 June-1 July 2000 Further details: Orga-Med Congress Office, $\mathrm{Mr}$ Peter Erard, Essenestraat 77, B-1740 Ternat, Belgium (tel: +32 258208 52; fax: +32 258255 15; email: orgamed@ village.uunet.be).

Imperial College School of Medicine, Division of Paediatrics, Obstetrics, and Gynaecology, New Horizons in Recurrent Pregnancy Loss, 29 June-1 July 2000 Further details: Symposium Office, Imperial College School of Medicine, Queen Charlotte's and Chelsea Hospital, Goldhawk Road, London W6 0XG (tel: 02083833904 fax: 0208383 8555; email: sympreg@ ic.ac.uk)

Imperial College School of Medicine, Division of Paediatrics, Obstetrics, and Gynaecology, Bereavement, 5 July 2000 Further details: Symposium Office, Imperial College School of Medicine, Queen Charlotte's and Chelsea Hospital, Goldhawk Road, London W6 0XG (tel: 0208383 3904; fax: 0208383 8555; email: sympreg@ic.ac.uk).

Imperial College School of Medicine, Division of Paediatrics, Obstetrics, and Gynaecology, Advances in Obstetric Medicine: International Meeting of $\mathrm{Ob}$ stetric Medicine Societies (satellite to ISSHP, Paris, 6-7 July 2000

Further details: Symposium Office, Imperial College School of Medicine, Queen Charlotte's and Chelsea Hospital, Goldhawk Road, London W6 0XG (tel: 02083833904 fax: 0208383 8555; email: sympreg@ic.ac.uk).

XIII International AIDS Conference, 9-14 July 2000, Durban, South Africa

Further details: Congrex Sweden AB, PO Box 5619, Linnegatan 89A, 11486 Stockholm, Sweden (tel: +46 8459 6600; fax: +46 866191 25; email: aids2000@congrex.se).

The Management of Genito-urinary Infections in Women, Royal Society of Medicine, London, 13-14 July 2000

3rd Congress of the Baltic Association of Dermatovenereology, 7-9 September 2000, Riga, Latvia

Further details: Professor Andris Y Rubins, Department of Dermatovenereology, Medical Academy of Latvia, K Valdemara Street, 76-75, Riga, LV-1013, Latvia (tel: +(371) 7370395; fax: +(371 7361615; email: arubins@apollo.lv).

National NCCG Uptake Meeting, Bromsgrove Stakis Hotel, 23-24 September 2000

Further details: Kathy Taylor (tel: 01384 235207; email: palmtraining@tesco.net).
Consortium of Thai Training Institutes for STDs and AIDS-10th STDs/AIDS diploma course, Bangkok Hospital, Bangkok (30 Oct-12 Nov) and Prince of Songkla University, Hat Yai, Thailand (13-23 Nov) 30 October-23 November 2000

Further details: Hat Yai Secretariat, Dr Verapol Chandeying, Dept of OB-GYN, Faculty of Medicine, Prince of Songkla University, Hat Yai, Songkla 90110, Thailand (fax: (66-74) 446 361; email: cverapol@ratree.

psu.ac.th or Bangkok Secretariat, Dr Thanit Palanuvej, Bangkok Hospital, 189 Sathorn Road, Bangkok 10120, Thailand (fax: (66-2) 286 3013; email: pthanit@email.ksc.net).

Consortium of Thai Training Institutes for STDs and AIDS-International Reunion and Refresher Course on Sexual Health, Lee Garden Plaza Hotel, Hat Yai, Thailand 24-26 November 2000

Further details: Hat Yai Secretariat, Dr Verapol Chandeying, Dept of OB-GYN, Faculty of Medicine, Prince of Songkla University, Hat Yai, Songkla 90110, Thailand (fax: (66-74) 446 361; email: cverapol@ratree.

psu.ac.th or Bangkok Secretariat, Dr Thanit Palanuvej, Bangkok Hospital, 189 Sathorn Road, Bangkok 10120, Thailand (fax: (66-2) 286 3013; email: pthanit@email.ksc.net).

\section{CORRECTION}

An error occurred in an original article by Hughes et al that appeared in the February issue of the journal $(2000 ; 76: 18-24)$. In the participants section under West Midlands, "Dr Wade, Coventry and Warwickshire Hospital" should read "Dr Wade and Dr Allan, Coventry and Warwickshire Hospital."

\section{CURRENT PUBLICATIONS}

Selected titles form recent reports published worldwide are arranged in the following sections:

Gonorrhoea

Chlamydia

Candidiasis

Bacterial vaginosis

Trichomoniasis

Pelvic inflammatory disease

Syphilis and other treponematoses

Hepatitis

Herpes

Human papillomavirus infection

Cervical cytology and colposcopy

Other sexually transmitted infections

Public health and social aspects

Microbiology and immunology

Dermatology

Miscellaneous 


\section{Gonorrhoea}

Neisseria gonorrhoeae infections in girls younger than 12 years of age evaluated for vaginitis.

RA SHAPIRO, CJ SCHYBert, RM SIEGel. Pediatrics 1999;104:E721-30

Opa expression correlates with elevated transformation rates in Neisseria gonorrhoeae.

SA HILL. $\mathcal{F}$ Bacteriol 2000;182:171-8

\section{Chlamydia}

Chlamydia trachomatis infection as a risk factor for invasive cervical cancer. P KOSKela, T ANTTILA, T BJORGe et al. Int $\mathcal{F}$ Cancer 2000;85:35-9

Screening for Chlamydia trachomatis in subfertile women.

s MACMILLAN, a templeton. Hum Reprod 1999;14:3009-12

Analysis of Chlamydia trachomatis serovars in endocervical specimens derived from pregnant Japanese women. $\mathrm{J}$ IKEHATA, K NUMAZAKI, S CHIBA. Fems Immunol Med Microbiol 2000;27:35-42

Molecular epidemiology of genital Chlamydial trachomatis infection in high-risk women in Senegal, West Africa.

K STURMRANIREZ, H BRUMBLAY, K DIOP et al. $\mathcal{F}$ Clin Microbiol 2000;38:138-45

Evaluation of a rapid assay for detection of Chlamydia trachomatis infections in outpatient clinics in South Kalimantan, Indonesia.

S WIDJAJA, S COHEN, WE BRADY et al. $\mathcal{F}$ Clin Microbiol 1999;37:4183-8

Seroactivity to Chlamydia trachomatis Hsp10 correlates with severity of human genital tract disease.

D LAVERDA, LN ALBANESE, PE RUTHER et al. Infect Immun 2000;68:303-9

Immunogenic and protective ability of the two developmental forms of Chlamydiae in a mouse model of infertility.

S PAL, J RANGEL, EM PETERSON, LM DELAMAZA. Vaccine 1999;18:752-63

Subclinical chlamydial infection of the female mouse genital tract generates a potent protective immune response: implications for development of live attenuated chlamydial vaccine strains.

$\mathrm{H}$ SU, R MESSER, W WHITMIRE. Infect Immun 2000;68:192-6

Isolates of Chlamydia trachomatis that occupy nonfusogenic inclusions lack IncA, a protein localized to the inclusion membrane.

RJ SUCHLAND, DD ROCKEY, JP BANNANTINE, WE STAMM. Infect Immun 2000;68:360-7
The intercellular adhesion molecule type-1 is required for rapid activation of T helper type 1 lymphocytes that control early acute phase of genital chlamydial infection in mice.

JU IGIETSEME, GA ANANBA, J BOLIER et al. Immunology 1999;98:510-8

\section{Candidiasis}

Species and genotypic diversities and similarities of pathogenic yeasts colonizing women.

JP XU, CM BOyD, E LIVINGSTON et al. $\mathcal{f}$ Clin Microbiol 1999;51:3835-50

Isolated candidal prostatitis.

A ELERT, R VONKNOBLOCH, R NUSSER et al. $\mathcal{F}$ Urol 2000;163:244

Multilocus genotypes and DNA fingerprints do not predict variation in azole resistance among clinical isolates of Candida albicans.

LE COWEN, C FIRJUSINGH, RC SUMMERBELL et al. Antimicrob Agents Chemother 1999;43:293042

\section{Bacterial vaginosis}

Prevalence of bacterial vaginosis and correlation of clinical to gram stain diagnostic criteria in low risk pregnant women.

E GRATACOS, F FIGUERAS, M BARRANCO et al. Eur F Epidemiol 1999;15:913-6

Direct or referral microsopy of vaginal wet smear for bacterial vaginosis: experience from an STD clinic.

CS PETERSEN, Ag DANIELSEN, J RENNEBERg. Acta DermatoVenereol 1999;79:473-4

\section{Trichomoniasis}

Improved diagnosis of Trichomonas vaginalis infection by $P C R$ using vaginal swabs and urine specimens compared to diagnosis by wet mount microscopy, culture and fluorescent staining.

C VANDERSCHEE, A VANBELKUM, L ZWIJGERS $e t$ al. f Clin Microbiol 1999;37:4127-34

Use of spun urine to enhance detection of Trichomonas vaginalis in adolescent women.

DR Clake, a DUgGan, a Joffe. Arch Pediat Adolesc Med 1999;153:1222-5

Identification of Trichomonas vaginalis $\alpha$-actinin as the most common immunogen recognized by sera of women exposed to the parasite.

MF ADDIS, P RAPPELLI, AMP DEANDRADE $e t$ al. $\mathcal{F}$ Infect Dis 1999;180:1727-30

\section{Pelvic inflammatory disease}

Prevalence and incidence of chronic pelvic pain in primary care: evidence from a national general practice database. KT ZONDERVAN PL YUDKIN, MP VESSEY et al. $\mathrm{Br} \mathcal{F}$ Obstet Gynaecol 1999;106:1149-55

Patterns of diagnosis and referral in women consulting for chronic pelvic pain in UK primary care.

KT ZONDERVAN, PL YUDKIN, MP VESSEY et al. $\mathrm{Br} \mathcal{F}$ Obstet Gynaecol 1999;106:1156-61

\section{Syphilis and other treponematoses}

Response to standard syphilis treament in patients infected with the human immunodeficiency virus.

J BORDON, C MARTINEZVAZQUEZ, J DELAFUENTEAGUADO et al. Eur $\mathcal{f}$ Clin Microbiol Infect Dis 1999;18:729-32

Identification of Treponema pallidum susbspecies pallidum in a 200 -year-old skeleton specimen.

CJ KOLMAN, A CENTRURIONLARA, SA LUKEHART $e t$ al. F Infect Dis 1999;180:2060-3

Validation of the INNO-LIA syphilis kit as a confirmatory assay for Treponema pallidum antibodies.

A EBEL, L VANNESTE, M CARDINAELS et al. $\mathcal{F}$ Clin Microbiol 2000;38:215-9

\section{Hepatitis}

Low risk of vertical transmission of hepatitis $\mathrm{C}$ virus by breast milk.

S POLYWKA, M SCHROTER, HH FEUCHT et al. Clin Infect Dis 1999;29:1327-9

Urine from chronic hepatitis $B$ virus carriers: implications for infectivity. M KNUTSSON, K KIDDLJUNGGREN. $\mathcal{f}$ Med Virol 2000;60:17-20

\section{Herpes}

Prevalence and incidence of herpes simplex virus type 2 infection among male Zimbabwean factory workers.

W MCFARLAN, L GWANZURA, MT BASSETT et al. $\mathcal{F}$ Infect Dis 1999;180:1459-65

Relation between herpes simplex viruses and human immunodeficiency virus infections.

JL SEVERSON, SK TYRING. Arch Dermatol 1999;135:1393-7 
Persistent stress as a predictor of genital herpes recurrence.

F COHEN, ME KEMENY, KA KEARNey et al. Arch Intern Med 1999;159:2430-6

Rapid detection of HSV from cytologic specimens collected into ThinPrep fixative.

MD FIELGAN, CF VILLAMIL, SR MANDAVILLI et al. Acta Cytol 1999;43:1034-8

Treatment of primary herpes simplex virus infection in guinea pigs by imiquimod.

RL MILLER, LM IMBERTSON, MJ REITER, JF GERSTER. Antivir Res 1999;44:31-42

Protective immune correlates can segregate by vaccine type in a murine herpes model system.

JI SIN, V AYYAVOO, J BOYER et al. Int Immunol 1999;11:1763-74

Cellulose acetate phthalate (CAP): an 'inactive' pharmaceutical excipient with antiviral activity in the mouse model of genital herpesvirus infection.

T Gyotoku, l aurelian, ar neUrath. Antiviral Chem Chemother 1999;10:327-32

Co-infection of acyclovir-resistant and acyclovir-sensitive herpes simplex type 2 virus strains in BS-C- 1 cells.

K KEYWAN, E KATZ. Intervirology 1999;42:24751

Immune responses and protection against vaginal infection after nasal or vaginal immunization with attenuated herpes simplex virus type- 2 .

EL PARR, MB PARR. Immunology 1999;98:63945

Immunity induced by DNA immunization with herpes simplex virus type 2 glycoproteins $B$ and $C$.

JC MESTER, TA TWOMEY, ET TEPE, DI BERNSTEIN. Vaccine 1999;18:875-83

Persistence of infectious herpes simplex virus type 2 in the nervous system in mice after antiviral chemotherapy.

am thackray, HJ FIELD. Antimicrob Agents Chemother 2000;44:97-110

Repression of viral transcription during herpes simplex virus latency.

CM PRESTON. f Gen Virol 2000;81:1-20

The major neutralizing antigenic site on herpes simplex virus glycoprotein D overlaps a receptor-binding domain.

JC WHITBECK, MI MUGGERIDGE, AH RUX et al. $\mathcal{F}$ Virol 1999;73:9879-90

Herpes simplex virus type 2 glycoprotein G-negative clinical isolates are generated by single frame shift mutations.

JA LILJEQVIST, B SVENNERHOLM, T BERGSTROM. $\mathcal{f}$ Virol 1999;73:9796-809

Potential role for luman, the cellular homologue of herpes simplex virus VPA16 ( $\alpha$ gene trans-inducing factor) in herpesvirus latency.

R LU, V MISRA. f Virol 2000;74:934-43
Granzyme A, a noncytologic component of CD8(+) cell granlules, restricts the spread of herpes simplex virus in the peripheral nervous systems of experimentally infected mice.

RA PEREIRA, MM SIMON, A SIMMONS. F Virol 2000;74:1029-42

Intracellular localization of the UL31 protein of herpes simplex virus type 2 . HY ZHU, H YA,ADA, YM JIANG et al. Arch Virol 1999;144:1923-36

\section{Human papillomavirus infection}

Pernicious papillomavirus infection. RD BURK. N Engl f Med 1999;341:1687

Type-specific persistence of human paillomavirus DNA before the development of invasive cervical cancer.

KL WALlin, F WIKLUND, T ANGSTROM et al. $N$ Engl f Med 1999;341:1633-8

Epidemiology of acquisition and clearance of cervical human papillomavirus infection in women from a high-risk area for cervical cancer.

EL FRANCO, LL VILLA, JP SOBRINHo et al. F Infect Dis 1999;180:1415-23

HPV transmission-still feeling the way. A MINDEL, R TIDEMAN. Lancet 1999;354:2097

HPV DNA testing of self-collected vaginal samples compared with cytologic screenng to detect cervical cancer.

TC WRIGHT, L DENNY, L KUHN et al. $\mathfrak{F} A M A$ 2000;283:81-6

HPV DNA testing in cervical cancer screening: results from women in a high-risk province of Costa Rica.

M SCHIFFMAN, R HERRERO, A HILDESHEIM et al. fAMA 2000;283:87-93

Human papillomavirus testing for primary cervical cancer screening. J CUZICK. $\mathcal{F} A M A$ 2000;283:108-13

HPV-based cervical cancer screening in a population at high risk for $\mathrm{HIV}$ infection.

SD WOMACK, ZM CHIRENJE, L GAFFIKIN et al. Int $\mathcal{F}$ Cancer 2000;85:206-10

Screening for cervical neoplasia by selfassessment for human papillomavirus DNA.

P HILLEMANNS, R KIMMIG, U HUTTEMANN et al. Lancet 1999;354:1970

Spontaneous evolution of human papillomavirus infection in the uterine cervix-a prospective observational study. E PARASKEVAIDIS, SM KALANTARIDOU, I GEORGIOU et al. Anticancer Res 1999;19:3473-8

Seroreactivity to human papillomavirus type $16,18,31$ and 45 virus-like particles in a case-control study of cervical squamous intraepithelial lesions.

L WIDEROFF, M SCHIFFMAN, P HADERER et al. $\mathcal{F}$ Infect Dis 1999;180:1424-8
Anal intraepithelial neoplasia. JH SCHOLEFIELD. Br F Surg 1999;86:1363-4

A randomized, controlled, safety study using imiquimod for the topical treatment of anogenital warts in $\mathrm{HIV}$-infected patients.

RJC GILSON, JL SHUPACK, AE FRIEDMANKIEN $e t$ al. AIDS 1999;13:2397-2404

Human papillomavirus type 16 E6 variants in cervical carcinoma: relationship to host genetic factors and clinical parameters.

CS BRADY, MF DUGGANKEEN, JA DAVIDSON et al. $\mathcal{f}$ Gen Virol 1999;80:3233-40

Favorable clinical outcome of cervical cancers infected with human papilloma virus type 58 and related types.

HC LAI, CA SUN, MH YU et al. Int $\mathcal{f}$ Cancer 1999;84:553-7

Seroepidemiology of human papillomavirus type 73: a sexually transmitted low-risk virus.

KL WALLIN, GJJ VANDOORNUM, A ANDERSSONELLSTROM et al. Int f Cancer 2000;85:353-7

Improved amplification of genital human papillomaviruses.

OE GRAVITT, CL PEYTON, TQ ALESSI et al. $\mathcal{f}$ Clin Microbiol 2000;38:357-61

Additional human papillomavirus types detected by the hybrid capture tube test among samples from women with cytological and colposcopical atypia.

J KONYA, G VERESS, A JUHASZ et al. $\mathcal{F}$ Clin Microbiol 2000;38:408-21

PCR-RFLP-detected human papilloma virus infection in a group of Senegalese women attending an STD clinic and identification of a new HPV-68 subtype. G ASTORI, A BELTRAME, C PIPAN et al. Intervirology 1999;42:247-51

Detection of human papilloma virus genomes by the primed in situ (PRINS) labelling technique.

M RAMAEL, H VANSTEELANDT, G STUYVEN et al. Path Res Practice 1999;195:801-8

DNA vaccination of mice with plasmid expressing human papillomavirus 6 major capsid protein $\mathrm{L} 1$ elicits typespecific antibodies neutralizing pseudovirions constructed in vitro.

K MATSUMOTO, K KAWANA, H YOSHIKAWA et al. $\mathcal{F}$ Med Virol 2000;60:200-4

Capture ELISA and in vitro cell binding assay for the detection of antibodies to human papillomavirus type $6 \mathrm{~b}$ virus-like particles in patients with anogenital warts.

SW PENG, YM QI, N CHRISTENSEN et al. Pathology 1999;31:418-24

Detection of high-risk cervical intraepithelial neoplasia and cervical cancer by amplification of transcription derived from integrated papillomavirus oncogenes.

R KLAES, SM WOERNER, R RIDDER et al. Cancer Res 1999;59:6132-6 
Antibodies against oncoproteins E6 and E7 of human papillomavirus types 16 and 18 in cervical-carcinoma patients from Russia.

K ZUMBACH, F KISSELJOV, O SACHAROVA et al. Int $\mathcal{F}$ Cancer $2000 ; 85: 313-8$

HPV 16 E6 blocks TNF-mediated apoptosis in mouse fibroblasts $\mathrm{LM}$ cells.

PJ DUERKSENHUGHES, J YANG, SB SCHWARTZ. Virology 1999;264:55-65

CD4(+) tumor-infiltrating lymphocytes in cervical cancer recognize HLA-DRrestricted peptides provided by human papillomavirus-E7.

H HOHN, H PILCH, s GUNZEL et al. $\mathcal{F}$ Immunol 1999;163:5715-22

The E6 protein of human papillomavirus type 16 binds to and inhibits coactivation by CBP and p300.

D PATEL, SM HUANG, LA BAGLIA, DJ MCCANCE. EMBO f 1999;18:5061-72

The human papillomavirus type 16 E5 protein modulates phospholipase $\mathrm{C}-\gamma-1$ activity and phospatidyl inositol turnover in mouse fibroblasts.

K CRUSIOS, M KASZKIN, V KINZEL, A ALONSO. Oncogene 1999;18:6714-8

Interaction between the HPV-16 E2 transcriptional activator and $\mathrm{p} 53$.

P MASSIMI, D PIM, C BERTOLI et al. Oncogene 1999;18:7748-54

The E8 $\cap$ E2C protein, a negative regulator of viral transcription and replication, is required for extrachromosomal maintenance of human papillomavirus type 31 in keratinocytes.

F STUBENRAUCH, M HUMMEL, $T$ IFYNER, LA LAIMINS. F Virol 2000;74:1178-99

The differentiation-specific factor CDP/ Cut represses transcription and replication of human papillomaviruses through a conserved silencing element.

MK OCONNOR, w STUNKEL, CH KOH et al. F Virol 2000;74:401-10

\section{Cervical cytology and colposcopy}

Cervical cytology after 2000: where to go? CJLM MeIJER, JMM walboomers. I Clin Pathol 2000;53:41-3

Comparative evaluation of seven cell collection devices for cervical smears.

PD KOHLBERGER, J STANI, G GITSCH et al. Acta Cytol 1999;43:1023-26

Efficacy of cervical smear collection devices: a systemic review and metaanalysis.

P MARTINHIRSCH, R LILFORD, G JARVIS, HC KITCHENER, Lancet 1999;354:1763-70

Detection of false-negative Papanicolaou smears by rapid rescreening in a large routine cervical cytology laboratory.

RG WRIGHT, JA HALFORD, EJ DITCHMAN. Pathology 1999;31:379-81
Determining the cost-effectiveness of mass screening for cervical cancer using common analytic models.

s Cato, g matunaga, i truji et al. Acta Cytol 1999;43:1006-14

A prototype computer image-based $\mathbf{P a}$ panicolaou smear proficiency test.

RN TAYlor, M GAGNON, J LANGe, T LEE et al. Acta Cytol 1999;43:1045-51

The diagnostic value of computerassisted primary cervical smear screening: a longitudinal cohort study.

H DOORNEWAARD, YT VANDERSCHOUW, Y VANDERGRAAF et al. Mod Pathol 1999;12:995-1000

Detection of human herpesvirus 8 in cervical cells of Chinese women with abnormal Papanicolaou smears.

PKS CHAN, WH KI, MYM CHAN, AFB CHENG. Clin Infect Dis 1999;29:1584-5

A study of the follow up patterns of women treated for CIN 2 and 3 before and after the introduction of the 1992 guidelines.

CH MANN, S KEHOE, A BROWN, CM LUESLEY. $\mathrm{Br} \mathcal{F}$ Obstet Gynaecol 1999;106:1126-9

Cidofovir, a new approach for the treatment of cervix intraepithelial neoplasiaa grade III (CIN III).

R SNOECK, JC NOEL, C MULLeR et al. $\mathcal{F}$ Med Virol 2000;60:205-9

Effects of chemotherapy and tamoxifen on cervical and vaginal smears in bone marrow transplant recipients.

K liU, J marshall, hs shaw et al. Acta Cytol $1999 ; 43: 1027-33$

Serum carotenoids and vitamins and risk of cervical dysplasia from a casecontrol study in Japan.

C NAGATA, H SHIMIZU, H Yoshikawa et al. $\mathrm{Br} F$ Cancer 1999;81:1234-7

Vaginal 5-fluorouracil for high-grade cervical dysplasia in human immunodeficiency virus infection: a randomized trial

M MAIMAN, DH WATTS, J ANDERSEN et al. Obstet Gynecol 1999;94:954-61

Preclinical feasibility study of NMP179, a nuclear matrix protein marker for cervical dysplasia.

SK KEESEE, JL MEYER, ML HUTCHINSON et al. Acta Cytol 1999;43:1015-22

Fhit alterations in cancerous and noncancerous cervical epithelium.

K YOSHINO, T ENOMOTO, T NAKAMURA et al. Int $\mathcal{F}$ Cancer 2000;85:6-13

\section{Other sexually transmitted infections}

A randomized, double-blind, placebocontrolled trial of single-dose ciprofloxacin versus erthromycin for the treatment of chancroid in Nairobi, Kenya.

IM MALONZA, MW TYNDALL, JO NDINYAACHOLA et al. F Infect Dis 1999;180:188693
Cytolethal distending toxin of Haemophilus ducreyi induces apoptotic death of Jurkat $T$ cells.

$\mathrm{V}$ GELFANOVA, EJ HANSEN, SM SPINOLA. Infect Immun 1999;67:6394-6408

\section{Public health and social aspects}

Encouraging use of coupons to stimulate condom purchase.

Dw DAHL, GJ GORN, CB WeInBerg. Am $\mathcal{f}$ Public Health 1999;89:1866-8

\section{Microbiology and immunology}

Human herpesvirus 8 cellular immune responses in homosexual men.

HD STRICKLER, JJ GOEDERT, FR BETHKE et al. $\mathcal{F}$ Infect Dis 1999;180:1682-5

Correlation of behaviours with microbiological changes in vaginal flora. JR SCHWEBKE, CM RICHEY, HL WEISS. F Infect Dis 1999;180:1632-6

The identification of vaginal Lactobacillus species and the demographic and microbiologic characteristics of women colonized by these species.

MAD ANTONIO, SE HAWES, SL HILlIER. $\mathcal{F}$ Infect $D i$ s 1999;180:1950-6

Common mucosal immunity: a novel hypothesis.

FA MOORE. Ann Surg 2000;231:9-10

Immunoglobulin concentrations and antigen-specific antibody levels in cervicovaginal lavages of rhesus macaques are influenced by the stage of the menstrual cycle.

FX LU, ZM MA, T ROURKe et al. Infect Immun 1999;67:6321-40

Evaluation of the bacterial flora of the prostate using a 16s rRNA gene based polymerase chain reaction.

WW HOCHREITER, JL DUNCAN, AJ SCHAEFFER. $\mathcal{F}$ Urol 2000;163:127-30

\section{Dermatology}

Incidence of preputial lichen sclerosus in adults: histologic study of circumcision specimens.

O AYNAUD, D PIRON, JM CASANOVA. $\mathcal{F} A m$ Acad Dermatol 1999;41:923-6

Penile cancer among patients with genital lichen sclerosus.

MR NASCA, D INNOCENZI, G MICALI et al. $\mathcal{f} \mathrm{Am}$ Acad Dermatol 1999;41:911-4 
Vulvar lichen sclerosus: an immunologic study.

F SCRIMIN, S RUSTJA, R RADILLO et al. ObstetGynecol 2000;95:147-50

Guidelines for management of Bowen's disease.

NH COX, DJ EEDY, CA MORTON. Br $\mathcal{F}$ Dermatol 1999;141:633-41

Vulvar melanoma, biologically different from other cutaneous melanomas.

CJ DUNTON, D BERD. Lancet 1999;354:2013

Cytomegalovirus balanitis in a renal transplant recipient.

A RODRIGUEZ, B HILL, R GOPOLAN, GN SKLAR. F Urol 1999;162:2086

The imidazoquinolines, imiquimod and R-848 induce functional but not phenotypic systemic vasculitis.

RP BURNS, B FERBEL, M TOMAI et al. Clin Immunol 2000;94:13-23

\section{Miscellaneous}

The staying power of sexually transmitted diseases.

w CATES, G DALlabETTA. Lancet 1999;354:62

Breaking the silence surrounding rape. S RAMSAY. Lancet 1999;354:2018

Seasonal variations in sexual activity and their implications for sexual health promotion.

K WELLINGS, W MACDOWALL, M CATCHPOLE, J GOODRICH. J Roy Soc Med 1999;92:60-4

Future change in sexual behaviour? CE wood. Med F Aust 1999;171:662-5

Symptoms of reproductive-tract infection-not all that they seem to be. K TROLLOPEKUMAR. Lancet 1999;354:1745

Reproductive-tract infections in women in low-income, low prevalence situation: assessment of syndromic managment in Matlab, Bangladesh.

S HAWKES, L MORISON, S FOSTER et al. Lancet 1999;354:1776-81

High prevalence and incidence of sexually transmitted diseases in urban adolescent females despite moderate risk behaviors.

RE BUNNELL, L HAHLBERG, R ROLFs et al. F Infect Dis 1999;180:1624-31
Sexual and reproductive health: what about boys and men: Education and service provision are the keys to increasing involvement.

G YAMEY. BMF 1999;319:1315

Male adolescents and physician sex preference.

CJ VANNESs, DA LYNCH. Arch Pediat Adolesc Med 2000;154:49-54

Repeated school-based screening for sexually transmitted diseases: a feasible strategy for reaching adolescents.

DA COHEN, M NSUAMI, DH MARTIN, TA FARLEY.

Pediatrics 1999;104:1281-5

Lesbians' sexual history with men: implications for taking a sexual history. AL DIAMANT, MA SCHUSTER, K MCGUIGAN, J LEVER. Arch Intern Med 1999;159:2730-8

Hysterectomy and sexual function.

JC RHODES, KH KJERULFF, RW LANGENBERG, GM GUZINSKI. $\mathscr{F} A M A$ 1999;282:1934-41

Perineal anatomy and urine-voiding characteristics of young women with and without recurrent urinary tract infections.

TM HOOTON, AE STAPLETON, PL ROBERTs et al. Clin Infect Dis 1999;29:1600-1

Prophylactic antibiotics for intrauterine device insertion: a metaanalysis of the randomized controlled trials.

DA GRIMES, KF SCHULZ. Contraception 1999;60:57-64

Genital pain without urogenital pathology: the koro-like syndorme.

JM CABALLERO, A AVILA, X CARDONA et al. $\mathcal{F}$ Urol 2000;163:243

Neurochemical characterization of the vestibular nerves in women with vulvar vestibulitis syndrome.

N BOHMSTARKE, M HILLIGES, C FALCONER, E RYLANDER. Gynecol Obstet Invest 1999;48: 270-5

Acupuncture for vulvodynia.

J POWEll, F wojnarowska. I Roy Soc Med 1999;92:579-81

Pudendal nerve injury associated with avid bicycling.

vs RICCHIUTI, CA HAAS, AD SEFTEL et al. F Urol 1999;162:2099
Prostate histopathology and the chronic prostatitis/chronic pelvic pain syndrome: a prospective biopsy study. LD TRUE, RE BERGER, I ROTHMAN et al. $\mathcal{f}$ Urol 1999;162:2014-8

Asthma and epididymitis: the calm before the storm.

GHM GEORgE, JS AXFORD. Ann Rheum Dis 1999;58:731-6

Male impotence.

A MORGENTALER. Lancet 1999;354:1713-8

Lack of diagnostic tools to prove erectile dysfunction: consequences for reimbursement?

K LEHMANN, R EICHLISBERGER, TC GASSER. $\mathcal{F}$ Urol 2000;163:91-4

Treatment of intracorporeal injection nonresponse with sildenafil alone or in combination with triple agent intracorporeal injection therapy.

CG MCMAHON, R SAMALI, H JOHNSON. $\mathcal{f}$ Urol 1999;162:1992-6

Tamoxifen versus placebo in the treatment of Peyronie's disease.

C TELOKEN, EL RHODEN, TM GRAZZIOTIN et al. $\mathcal{F}$ Urol 1999;162:2003-5

Iontophoresis for treatment of Peyronie's disease.

CR RIEDL, E PLAS, P ENGELHARDT et al. $\mathcal{F}$ Urol 2000;163:95-9

Behçet's syndrome: a multidisciplinary approach to clinical care.

AJ WHALLETT, G THURAIRAJAN, J HAMBURGER et al. Qf Med 1999;92:727-40

Is there a place for large vessel disease in the diagnostic criteria of Behçet's disease?

M SCHIRMER, KT CALAMIA, JD ODUFFY. $\mathcal{f}$ Rheumatol 1999;26:2511-2

Secondary inflammation of the appendix via the vagina.

SA BUtLermanuel, PT TOWNSEnd. I Roy Soc Med 1999;92:465

Two forms of reactive arthritis?

P TOIVAnen, A tolvanen. Ann Rheum Dis 1999;58:737-41

Reactive or infectious arthritis.

Jg KUlPers, L KOHLER, H ZEIDler. Ann Rheum Dis 1999;58:661-4

Beaver fever-a rare cause of reactive arthritis.

M TUPCHONG, A SIMOR, C DEWAR. I Rheumatol 1999;26:2701-2 